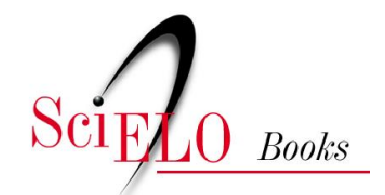

(1M) Mackenzie

\title{
O curso de Arquitetura da Escola de Engenharia Mackenzie
}

\author{
Marcel Mendes
}

\section{SciELO Books / SciELO Livros / SciELO Libros}

MENDES, M. O curso de Arquitetura da Escola de Engenharia Mackenzie. In: ALVIM, ATB., ABASCAL, EHS., and ABRUNHOSA, EC., orgs. Arquitetura Mackenzie 100 anos FAU-Mackenzie 70 anos: pionerismo e atualidade [online]. São Paulo: Editora Mackenzie, 2017, pp. 36-74. ISBN 97885-8293-726-6. Available from: doi: 10.7476/9788582937266. Also available in ePUB from: http://books.scielo.org/id/xrrzx/epub/alvim-9788582937266.epub.

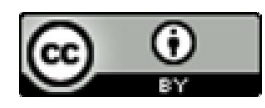

All the contents of this work, except where otherwise noted, is licensed under a Creative Commons Attribution $\underline{4.0 \text { International license. }}$

Todo o conteúdo deste trabalho, exceto quando houver ressalva, é publicado sob a licença Creative Commons Atribição 4.0.

Todo el contenido de esta obra, excepto donde se indique lo contrario, está bajo licencia de la licencia Creative Commons Reconocimento 4.0 . 
FACULDADE DE ARQUITETURA MACKENZIE:

ORIGENS, CONCEPÇÃO E PRINCÍPIOS (1917 A 1980) 


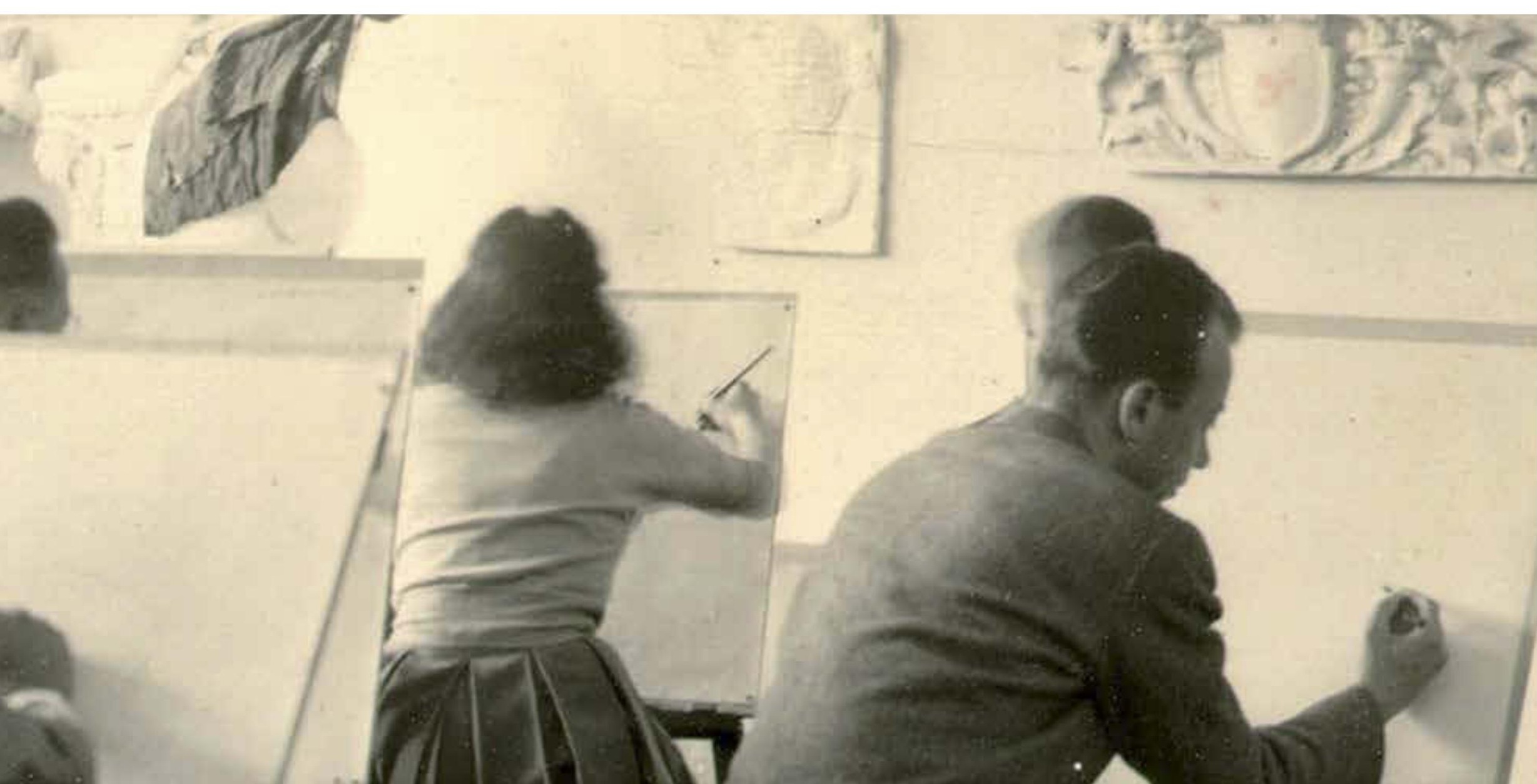


s/d. Alunos em uma aula de Desenho

ao ar livre ministrada pelo Prof. e

artista Theodoro Braga. Na foto, vê-

-se o Professor, o segundo da direita

para a esquerda (em pé), apoiado

no tronco da árvore, observando o

grupo de alunos desenhando.

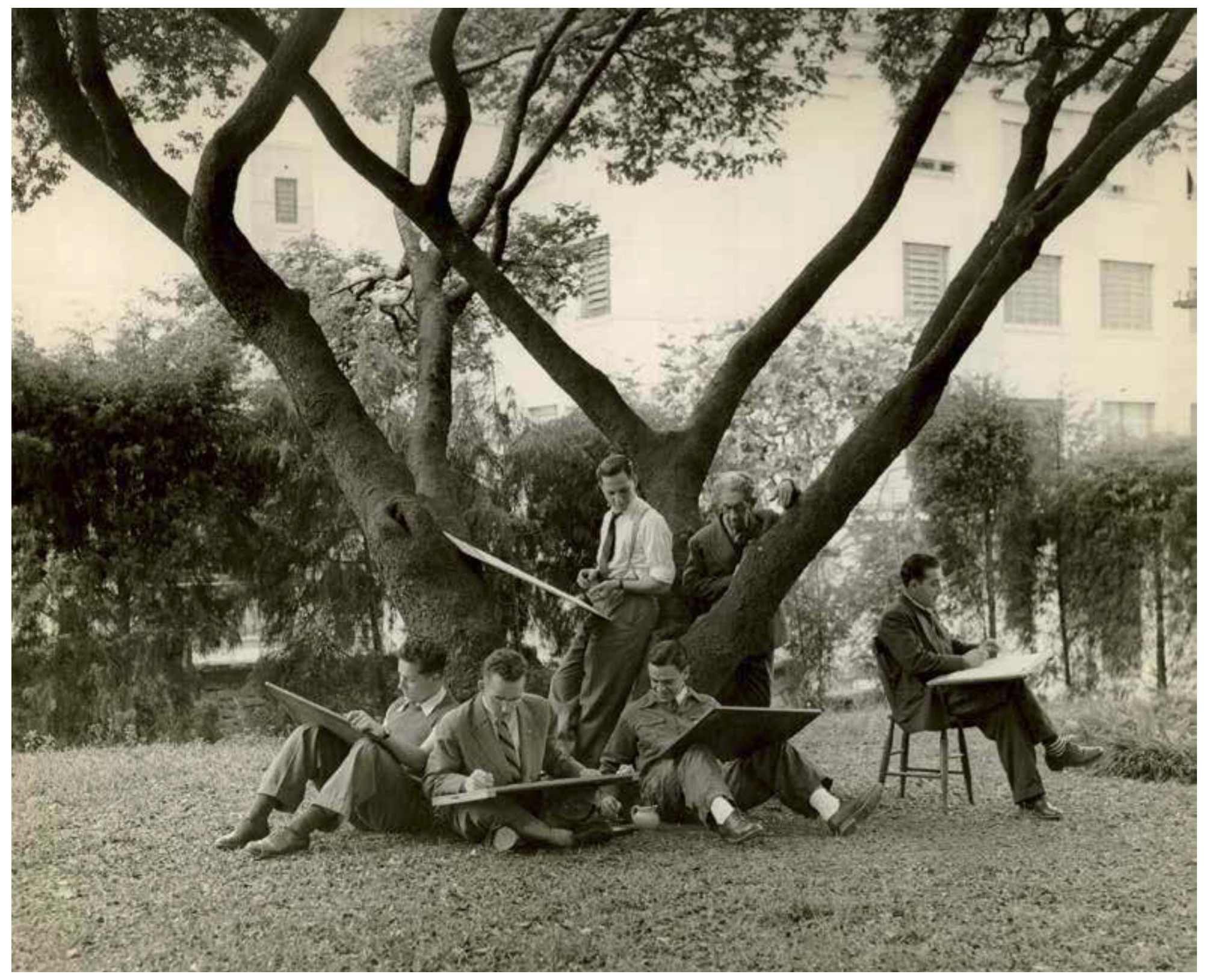




\section{O Curso de Arquitetura da Escola de Engenharia Mackenzie}

Marcel Mendes

\section{Introdução}

O objetivo deste capítulo é trazer à presença do leitor fragmentos históricos e tramas que possam iluminar a trajetória de três décadas do Curso de Arquitetura ministrado na antiga Escola de Engenharia Mackenzie College, curso que antecedeu a instalação da Faculdade de Arquitetura Mackenzie, no ano de 1947. A natureza do texto e a oportunidade da sua publicação indicam que este é um escorço panorâmico que não traduz, com a devida densidade de pontos e a conveniente nitidez de traços, todos os matizes e os contornos que esse quadro histórico poderia comportar.

Sobre o mesmo tema e em diferentes contextos, os Arquitetos-Pesquisadores Fernando Atique, Gustavo Pereira, Maria Teresa de Stockler e Breia e Sylvia Ficher - entre outros - produziram textos acadêmicos seminais. Essa constatação não impede que novas contribuições possam ser agregadas, pois, de acordo com o historiador Marc Bloch (2002, p. 75), se "o passado é, por definição, um dado que nada mais modificará, o conhecimento do passado é uma coisa em progresso, que incessantemente se transforma e aperfeiçoa". Para não perder a moldura e o foco do quadro, passemos de imediato aos tópicos da nossa breve elaboração temática.

\section{Origem do Curso de Arquitetura: formação de Engenheiros-Arquitetos}

Não é a primeira vez que se diz que o 'edifício' da Faculdade de Arquitetura e Urbanismo da Universidade Presbiteriana Mackenzie (FAU-Mackenzie) repousa solidamente sobre o 'alicerce' do Curso de Engenheiros-Arquitetos, construído a partir de 1917. Datam também dessa mesma época a Revista de Engenharia Mackenzie (1915), o Curso de Químicos Industriais (1916), o Curso de Engenheiros Mecânicos-Eletricistas (1917) e o Centro Acadêmico Horácio Lane (1918) - todos de alguma forma vinculados à tradicional Escola de Engenharia Mackenzie College, que já contava duas décadas de saliente atuação.

Imprimindo à sua dinâmica administração as marcas do crescimento e da diversificação, dirigia os destinos da instituição educacional presbiteriana de São Paulo William A. Waddell (1862-1939). Além de bacharel em Artes e Ciências e Doctor Honoris Causa em Filosofia e Teologia, Waddell também era engenheiro civil e, nessa condição, exercera, entre 1893 e 1895, a direção técnica das obras do Edifício Mackenzie, sede primitiva da Escola de Engenharia Mackenzie College - a mais antiga do Brasil dentre as instituições privadas de 


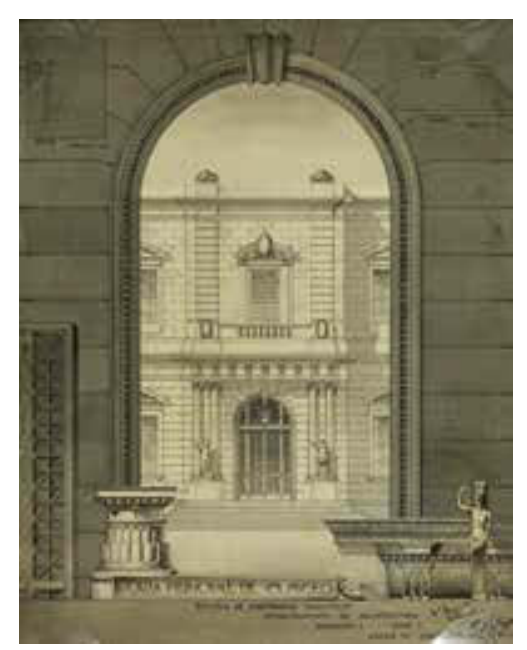

Ca.1932. Projeto porta principal de um Museu - Walter Saraiva Kneese (Mackenzie, 1934).

1. Cargo aproximadamente equivalente ao de Coordenador de Curso, mais próximo do título de Diretor.

2. Equivalente a um Conselho de Curadores, nomeado pela Igreja Presbiteriana dos Estados Unidos.

3. Na transição entre Horace Lane e William Waddell, o cargo de Presidente do Mackenzie College foi ocupado pelo Rev. Donald C. McLaren (1859-1930).

4. Sobre o tema "pan-americanismo" e seus desdobramentos, ver Atique (2007, p. 22-41).

5. O Arquiteto George Henry Krug foi designado pela University of the State of New York (USNY) para ocupar a vaga deixada pelo geólogo norte-americano Orville Adelbert Derby (1851-1915), que era vinculado a Cornell University. Segundo Atique (2007, p. 162), a USNY não deve ser confundida com a atual State University of New York (Suny), criada apenas em primeiro de julho de 1948. A antiga USNY encontrase atualmente vinculada ao State Department of Education of New York e funciona como órgão supervisor de ensino superior no Estado de Nova York. ensino de Engenharia - e atual endereço do Centro Histórico e Cultural Mackenzie (CHCM). Depois de ter sido por algum tempo Deão ${ }^{1}$ do Curso de Engenharia Civil, William Waddell transferiu-se em 1899 para o estado da Bahia, onde desempenhou múltiplas funções de pastor-missionário-engenheiro-educador, até retornar novamente ao Mackenzie College, em 1914, convidado pelo Board of Trustees de Nova York, ${ }^{2}$ para ocupar a vaga de presidente, recentemente deixada pelo médico-educador-filantropo Horace M. Lane (1837-1912), que morrera em 27 de outubro de 1912. ${ }^{3}$

No ano de 1916, William Waddell viajou aos Estados Unidos decidido a promover a aproximação do Mackenzie College em São Paulo com o Union College em Schenectady, estado de Nova York, local em que obtivera seus títulos acadêmicos, à exceção daquele de Teologia, que era do Princeton Theological Seminary. O jornal The New York Times Magazine de 25 de junho daquele ano divulgou ampla notícia sobre a presença do dirigente mackenzista no país, acrescentando ser uma auspiciosa experiência de pan-americanismo. ${ }^{4}$ A evocação dessa bandeira de integração pan-americana parece soar, na atualidade, um tanto ingênua, se for desvinculada da ideologia nela subjacente. Cabe até inserir aqui uma breve digressão, para mencionar que a influência dos Estados Unidos da América do Norte sobre a América Latina e Caribe encontrava-se num estágio promissor (do ponto de vista norte-americano), especialmente nas áreas estratégicas e básicas da economia, tais como mineração, energia e transporte, sendo clara, também, a penetração cultural por meio do cinema, da música e da literatura. Um exemplo desses vetores de sentido norte-sul materializou-se em São Paulo, nas décadas de 1910 a 1930, por meio do protagonismo da Fundação Rockefeller exercido na Faculdade de Medicina e Cirurgia de São Paulo e no delineamento da política de pesquisa, higiene e saúde pública do estado paulista. Fechemos o parêntese.

É preciso reconhecer que William Waddell não voltou dos Estados Unidos de mãos vazias; no mínimo, conseguiu atrair o interesse da empresa General Electric para a criação de um moderno Curso de Engenheiros Mecânicos-Eletricistas no Mackenzie College, à época em que a difusão da eletricidade e suas aplicações se tornava crucial para a urbanização e industrialização de São Paulo, cidade que também estava em vias de iniciar sua fase de verticalização.

Naquele mesmo ano de 1916, assumiu as atribuições de inspetor da University of the State of New York (USNY) no Mackenzie College ${ }^{5}$ o Arquiteto brasileiro George H. Krug (1860-1919), formado pela School of Architecture - depois de 1920 denominada Fine Arts School - da Universidade da Pensilvânia, em Filadélfia, Estados Unidos. Nessas atribuições acadêmicas, George Krug substituía o notável geólogo Orville A. Derby (1851-1915), formado na Cornell University, que exercera essa representação da USNY desde 1895 até a data da sua trágica morte no Rio de Janeiro.

As conexões de George Krug com a instituição educacional presbiteriana de Higienópolis não eram recentes e tinham o viés confessional, uma vez que ele era presbi- 
teriano, assim como Horace Lane, antigo presidente do Mackenzie College. ${ }^{6}$ Essas relações tinham, no entanto, o viés profissional, pois, associado a seu pai, haviam construído em São Paulo, entre 1890 e 1892, o Hospital Samaritano, e de cujo corpo diretivo fazia parte o médico Horace Lane (HOMEM, 2011, p. 58). Em reforço a esses vínculos, George Krug fora professor das cadeiras de 'Arquitetura' e 'Construção' da Escola de Engenharia Mackenzie College, de 1899 a 1902, tornando-se também docente da Escola Politécnica de São Paulo entre 1904 e 1916 (FICHER, 2005, p. 87-88). Tudo indica que esses foram os primeiros contatos institucionais do Mackenzie com uma personalidade oriunda da Fine Arts School da Universidade da Pensilvânia. Cabe lembrar ainda que as peculiaridades do Mackenzie College exigiam paradigmas acadêmicos diferenciados para seus cursos superiores, e isso havia sido buscado em latitudes acima da linha do Equador, em tradicionais estabelecimentos de ensino situados no Estado de Nova York. Quanto à Filadélfia, não tardaria para que essas aproximações se concretizassem, ainda que de forma indireta, especialmente em função de uma nova e relevante presença que estava para irromper no palco dos acontecimentos e que se tornaria elemento-chave para a criação do Curso de Engenheiros-Arquitetos no Mackenzie College: tratava-se de Christiano Stockler das Neves (1889-1982).

\section{Entra em cena o Arquiteto Christiano Stockler das Neves}

O Arquiteto Christiano Stockler das Neves, filho do construtor e engenheiro Samuel Augusto das Neves (1863-1937), havia chegado recentemente dos Estados Unidos, onde conquistara sua "Proficiência em Arquitetura" (ATIQUE, 2010, p. 5-14) na já mencionada School of Architecture (Fine Arts School) da Universidade da Pensilvânia, no período de 1909 a 1911. Completava, assim, a formação profissional iniciada em 1907 no Curso de Engenheiros-Arquitetos da Escola Politécnica de São Paulo. Entre sua saída daquele campus norte-americano e sua chegada a São Paulo, ele cumpriu extenso roteiro cultural na Europa, visitando bibliotecas, livrarias, exposições e instituições educacionais em mais de duas dezenas de cidades (BREIA, 1995, p. 134).

Como se verá adiante, a presença de Christiano Stockler das Neves no ambiente educacional da cidade de Filadélfia significou para o jovem Arquiteto paulista um marco indelével na sua formação. Dentre outras interações de ordem acadêmica e cultural, ele teve o privilégio de ali privar da presença do renomado Arquiteto francês Paul Philippe Crét (1876-1945), formado na École Nationale de Beaux-Arts de Lyon, e que atuava como professor da School of Architecture desde o começo do século XX, quando fora contratado. Por sua influência e de outros mestres oriundos da Europa, vinham sendo assimilados e incorporados métodos e princípios teóricos das escolas de belas artes francesas, com destaque para a École des Beaux-Arts de Paris. Isso não aconteceu como simples transposição, porquanto as influências pragmáticas norte-americanas impuseram certa simplificação nas questões ornamentais e incorporaram elementos técnicos à formação do Arquiteto,

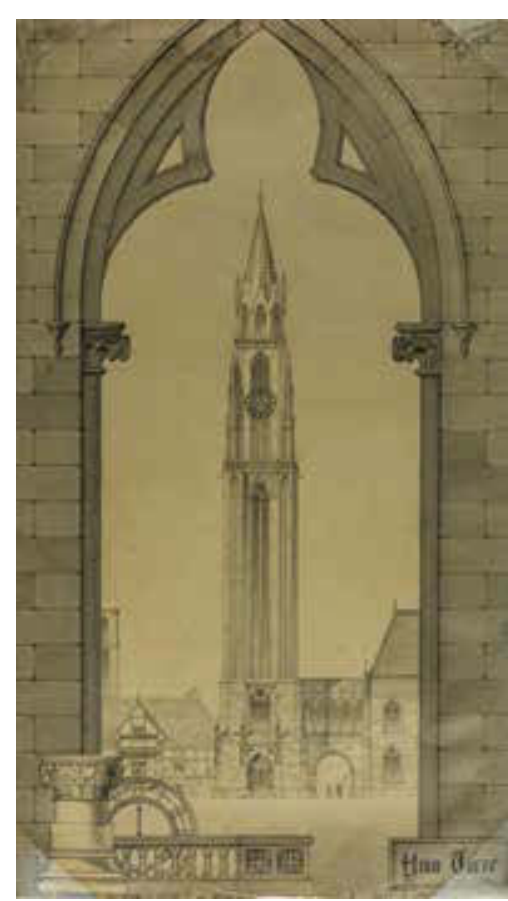

Ca. 1932. Projeto de uma Torre, do então estudante do Curso de Arquitetura da Escola de Engenharia do Mackenzie College, Engenheiro-Arquiteto Walter Saraiva Kneese.

6. Esta é uma inferência oferecida pelas fontes secundárias consultadas. 
1934. Estudo para uma Escola Profissional.

Autoria do Engenheiro-Arquiteto Walter

Saraiva Kneese, então discente do Curso

de Arquitetura da Escola de Engenharia do

Mackenzie College.

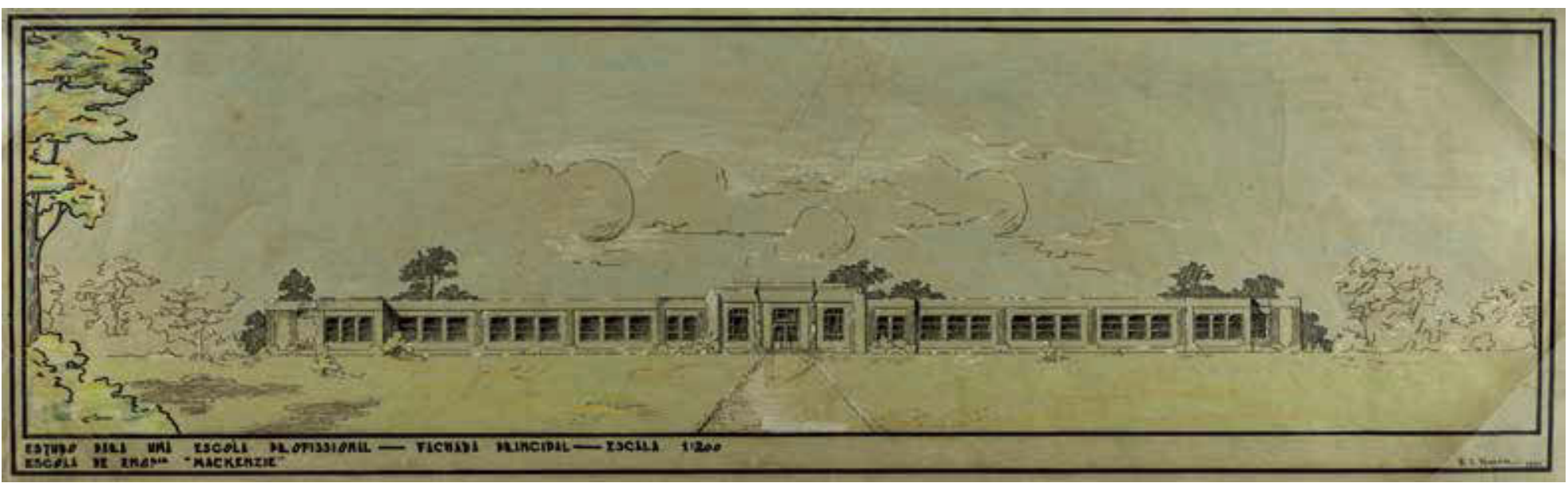

1934. Um Clube Náutico para Santo

Amaro. Estudo para um Clube Náutico

em Santo Amaro. Autoria do Engenheiro-

-Arquiteto Walter Saraiva Kneese.

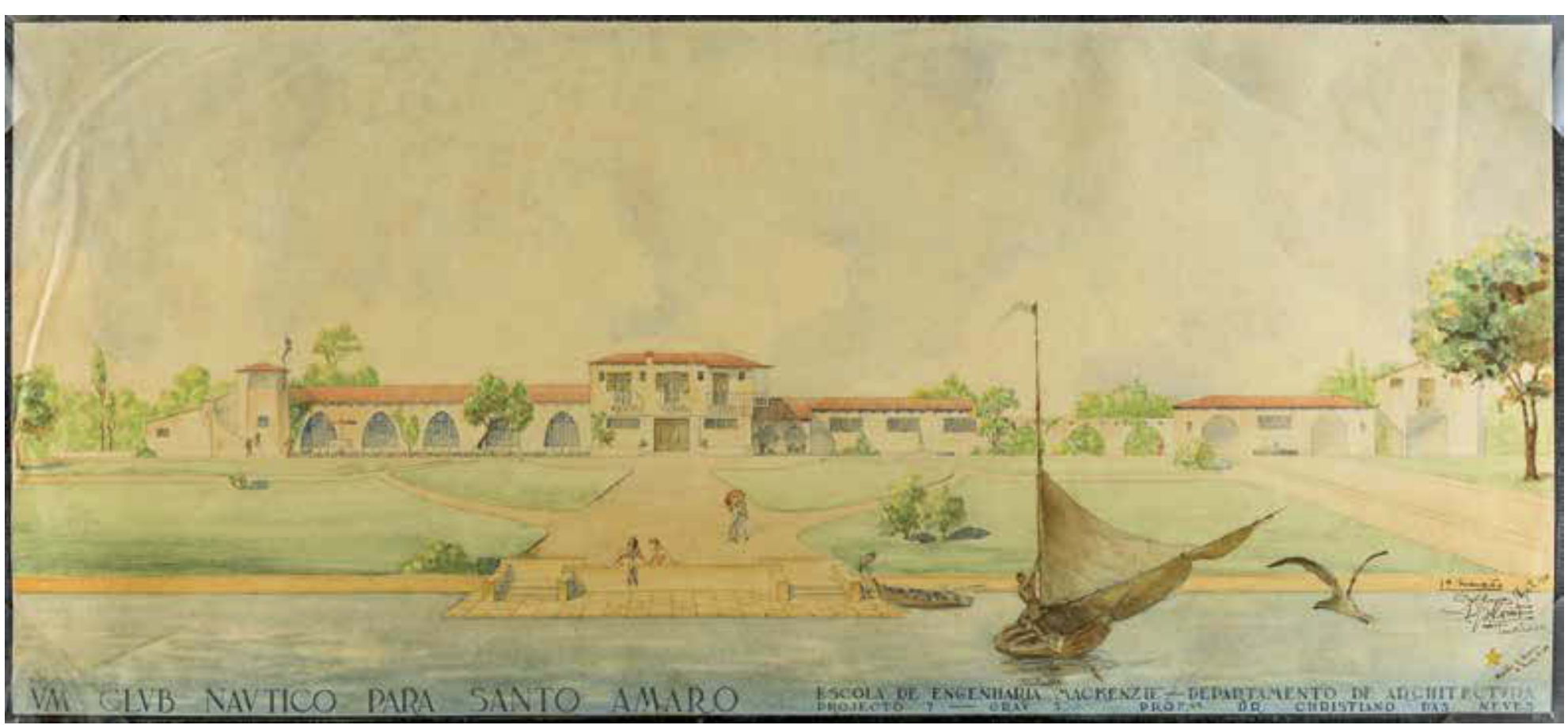


distinta, porém, daquela do Engenheiro. A partir de 1920, a então já consagrada School of Architeture veio a ampliar o leque das formações artísticas, adotando, concomitantemente, o nome pelo qual ficou mais conhecida na historiografia: Fine Arts School of the University of Pennsylvania - Penn (ATIQUE, 2007; 2009).

Retomemos a trajetória de Christiano Stockler das Neves, que, ao regressar a São Paulo, procurou aplicar e difundir, com as necessárias contextualizações, os conceitos que absorvera na Fine Arts School num esforço de síntese da tradição acadêmica francesa com as influências norte-americanas. Essa configuração fazia do Arquiteto o profissional com o maior volume de atribuições no processo projetivo e construtivo, em decorrência das suas elevadas competências estéticas, compositivas e técnicas, como se dizia. Das vertentes que então brotaram do fluente e impetuoso Christiano Stockler das Neves, destacamos aqui aquela relacionada com a formação de Arquitetos, que acabou desaguando no Mackenzie College. Nas palavras dele:

Empolgado com os magníficos métodos das universidades norte-americanas para o ensino de arquitetura, pensei, ainda nos bancos acadêmicos, em trazê-los para o nosso país. Aqui chegando, aguardei o momento oportuno para isso, na convicção de que faria obra patriótica e útil, organizando um curso, moldado nos das grandes instituições de ensino dos Estados Unidos. (ANUÁRIO, 1942, p. 40).

Essas coordenadas definem a confluência das trajetórias de William Waddell e Christiano Stockler das Neves, tendo como presença coadjuvante, porém estratégica, a figura de George Krug: um Engenheiro Civil e dois Arquitetos - todos formados em renomadas instituições acadêmicas dos Estados Unidos da América. Mais uma vez, nas palavras de Christiano Stockler das Neves (sic):

Efetivamente, sem visarmos qualquer interesse pecuniário, ocorreu-nos apresentar nossa idéia ao Mackenzie College, instituição livre e a única que estava em condições de aceitá-la, por adotar os mesmos métodos de ensino que fizeram a grandeza da terra do Tio Sam e que foram tão enaltecidas por Le Bon. Assim, dirigimo-nos à Diretoria desse estabelecimento, ocupada, interinamente pelo Prof. Slater, que interessou-se pela nossa proposta, resolvendo que se aguardasse o regresso do Dr. Waddell, nosso saudoso amigo e emérito educador, que se achava nos Estados Unidos. (REVISTA DE ENGENHARIA MACKENZIE, 1943, p. 2).

Como já referido, no primeiro semestre de 1916, o presidente do Mackenzie College encontrava-se em Schenectady, estado de Nova York, buscando apoio para a implantação do Curso de Engenheiros Mecânicos-Eletricistas. Esse desafio inaugural de William Waddell ganhou concretude já no ano seguinte, mas o ciclo de implantação de novos cursos superiores no Mackenzie estava apenas começando, a despeito da grave conjuntura internacional que 


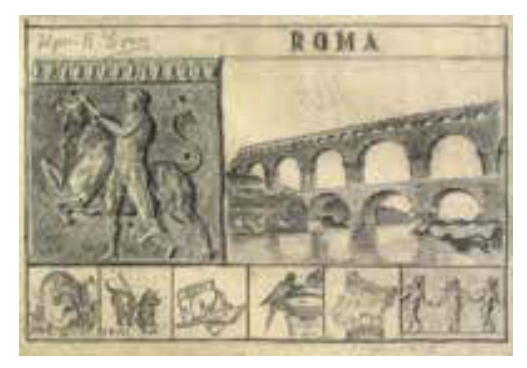

Ca.1945. Estudo a partir de referências da Arquitetura e Arte romanas. Autoria do Engenheiro Civil e Arquiteto Elgson Ribeiro Gomes (Mackenzie, 1958) registrava, dentre outras tragédias, a evolução da Primeira Guerra Mundial, com todo o seu impacto sobre a dinâmica social, comercial e econômica do planeta.

Ao retornar dos Estados Unidos, William Waddell abraçou prontamente a proposta de Christiano Stockler das Neves, solicitando, contudo, que ele não só lecionasse a cadeira de 'Composição Arquitetural', como era sua primeira intenção, mas que assumisse todas as disciplinas teóricas e práticas do Curso, aquelas específicas, não ministradas aos alunos de Engenharia Civil. Foi assim que nasceu, em 1917, o novo Curso de formação de Engenheiros-Arquitetos, vinculado à Escola de Engenharia Mackenzie College. A primeira turma, iniciada com apenas dois alunos que já cursavam Engenharia, convergiu na formatura de um único concluinte, o Engenheiro-Arquiteto Waldemar Kneese Ferreira. Isso foi em 1919.

Este é o momento de inserir um parágrafo para registrar que a origem da Faculdade de Arquitetura e Urbanismo do Mackenzie guarda interessante similitude à da Faculdade de Arquitetura e Urbanismo da Universidade de São Paulo (FAU-USP), pois esta também se constituiu a partir do Curso de Engenheiros-Arquitetos que havia sido criado na Escola Politécnica à época da sua instalação, em 1894, mas que começou a funcionar dois anos mais tarde. Segundo a pesquisadora Sylvia Ficher, até 1917 - ano da morte de Antônio Francisco de Paula Souza (1843-1917), fundador e primeiro diretor da Escola Politécnica - apenas 20 profissionais haviam se formado nesse tradicional estabelecimento de ensino superior público, evidenciando o reduzido interesse pelo título de Engenheiro-Arquiteto (FICHER, 2005, p. 11). Essa baixíssima média (menos de um profissional por ano) na Escola congênere atesta o quanto a proposta de Christiano Stockler das Neves foi produto de um sonho - "coisas da mocidade" -, como ele mesmo afirmou posteriormente (REVISTA DE ENGENHARIA MACKENZIE, 1943, p. 2). Nas palavras de Adolfo Morales de los Rios Filho, presidente do Conselho Federal de Engenharia e Arquitetura (Confea) por ocasião da criação da Faculdade de Arquitetura, em 1947, essa era uma "inaudita ousadia para aquele tempo, o estudo da Arquitetura no Mackenzie College. Tem a ampará-lo o decidido apoio dos mestres norte-americanos que dirigiam a instituição" (ANUÁRIO, 1949, p. 180). Atesta, também, o quanto o interesse do Mackenzie College pela implantação da nova carreira foi fruto de um ideal que só ganharia peso específico e foro de relevância mais à frente. Como se pode inferir, não foram as alavancas econômicas que moveram os projetos educacionais acalentados por esses protagonistas da história do ensino de Arquitetura em São Paulo: Christiano Stockler das Neves e William Waddell.

Em face da criação do novo Curso de Engenheiros-Arquitetos do Mackenzie College, é de se perguntar sobre suas características distintivas e marcas peculiares. A resposta parece imediata: no seu todo, a configuração do Curso teria sido inspirada no modelo das instituições norte-americanas, mais especificamente aquelas influenciadas pelas escolas de belas artes francesas. Seria essa uma premissa suficiente para delinear os rumos, justificar os métodos e assegurar a identidade diferenciada do Curso de Arquitetura do Mackenzie? Concernente a essa questão, Christiano Stockler das Neves, seu fundador e primeiro Deão (mais tarde, Diretor), fez afirmações categóricas: 
Trouxemos para aqui os magníficos métodos de ensino da grande arte civilizadora adotados nos Estados Unidos, onde fizemos os nossos estudos, métodos esses inspirados nos da Escola de Belas Artes de Paris, adaptados às necessidades do nosso continente. (ANUÁRIO, 1950, p. 131).

A menção à capital francesa sugere outro recorte de discurso de Christiano Stockler das Neves, que ajuda a entender como começou a funcionar o Curso de Arquitetura (sic):

Naqueles ditosos tempos, sem qualquer experiência no ensino, começamos o curso apenas com dois alunos, lutando com grandes dificuldades pela falta de livros didáticos em português, e em outros idiomas, para as salas da magna arte. Felizmente, possuíamos ótimo material para o ensino, adquirido em nossa viagem ao Velho Mundo, e que, até hoje, está servindo ao curso. (ANUÁRIO, 1949, p. 189).

A firmeza das declarações do 'criador' do Curso de Arquitetura do Mackenzie College, assim como a abundância de evidências históricas atestam a identidade diferenciada dessa singular 'criatura', cuja verdadeira ontologia jamais foi negada ou dissimulada. Resta, portanto, conhecer os traços da sua personalidade.

\section{Características do Curso de Arquitetura, formador de Engenheiros-Arquitetos}

Na sua origem, o Curso de Engenheiros-Arquitetos do Mackenzie College tinha cinco anos de duração, dos quais os primeiros dois constituíam tronco comum com a Engenharia Civil, e os três seguintes eram específicos. Para estes últimos, o professor era único e as aulas dos diversos anos escolares eram ministradas numa mesma sala, simultaneamente para diferentes grupos.

A primeira turma foi atendida exclusivamente por Christiano Stockler das Neves, mas, a partir da seguinte, o professor-fundador passou a contar com auxiliares recém-formados que foram, sucessivamente, os Engenheiros-Arquitetos Waldemar Kneese Ferreira (turma de 1919), Caetano Carnicelli (turma de 1920), José do Amaral Neddermeyer (turma de 1922) e Francisco José Esteves Kosuta (turma de 1925). Esse último fez carreira na FAU-Mackenzie, tornando-se catedrático de 'Geometria Descritiva', 'Elementos de Geometria Projetiva' e 'Perspectiva', e substituto eventual do próprio Christiano Stockler das Neves na direção do Curso.

Em 1922, o presidente do Mackenzie College, William Waddell, informou ao Board of Trustees de Nova York sobre o andamento do Curso que formava Engenheiros-Arquitetos. Tratava também do desempenho e qualificação profissional do seu responsável (Deão) e sobre as necessidades futuras:

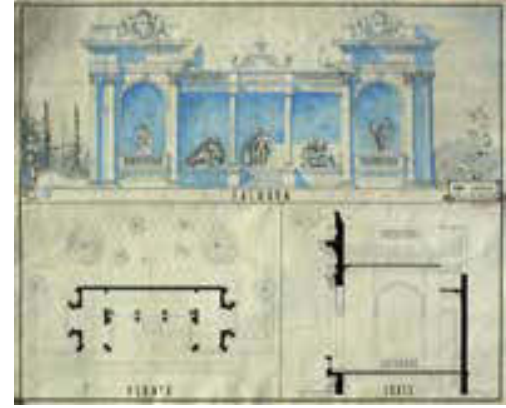

Ca.1947. Projeto de um monumento com Loggia. Autoria do Engenheiro Civil e Arquiteto Elgson Ribeiro Gomes (Mackenzie, 1958). 


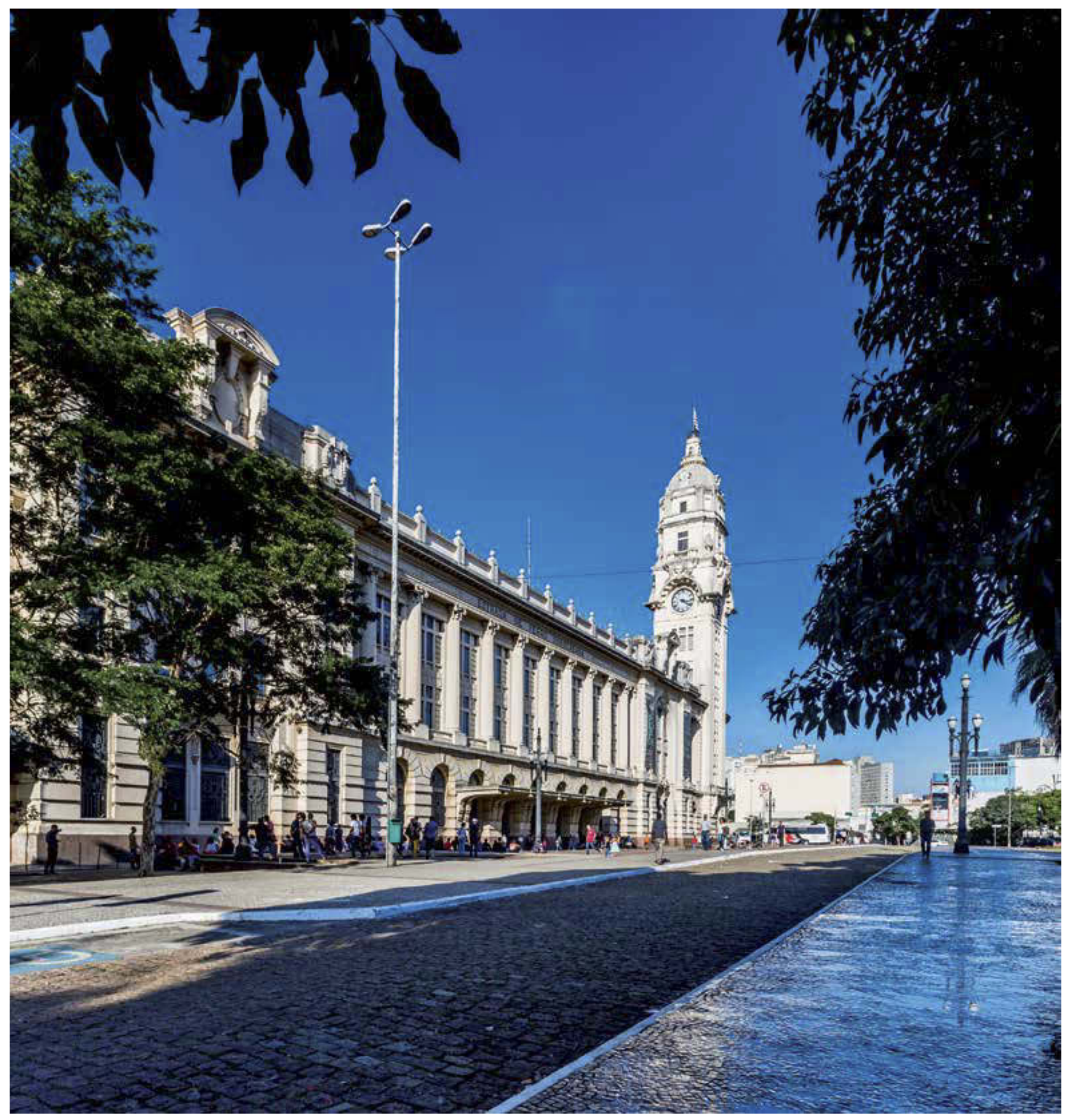


Nosso professor para Engenheiros-Arquitetos, Sr. Christiano Stockler das Neves, graduado na Universidade da Pennsylvania, acaba de conquistar o primeiro lugar no concurso para os projetos das estações ferroviárias de São Paulo e do Rio e ganhou a o contrato. Ele será o maior arquiteto do Brasil, se já não o é. Ele tem oferecido a nós, e isso é praticamente um presente, parte de seu tempo para fins de inspeção; o ensino é feito por outros. Se vocês pudessem encontrar um arquiteto norte-americano seria uma grande vantagem, mas ele deve ser um projetista melhor do que o norte-americano comum, e versado em problemas de construções em aço e concreto. (MACKENZIE COLLEGE, 1922, p. 12, tradução nossa).

Enquanto William Waddell e Christiano Stockler das Neves aguardavam a chegada desse Arquiteto estadunidense versado em estruturas de aço e de concreto, foi preciso reforçar o quadro docente com profissionais nativos. A primeira contratação externa foi a do Prof. Theodoro José da Silva Braga (1872-1953), artista dos mais ilustres, que assumiu as disciplinas 'História da Arte', 'Desenho a Mão Livre', 'Aquarela' e 'Modelagem'. Seguiram-se na docência os Engenheiros-Arquitetos Antonio Gallo Ferrigno (turma de 1922), Eduardo Augusto Kneese de Mello (turma de 1931) e Manoel Carlos Gomes de Soutello (turma de 1937) - todos mackenzistas. A segunda contratação externa deu-se apenas em 1939, ocasião em que o conhecido Engenheiro-Arquiteto Bruno Simões Magro (1882-1956) ingressou na Escola de Engenharia Mackenzie para lecionar no Curso de Arquitetura as disciplinas de 'Urbanismo', 'Prática Profissional' e 'Organização do Trabalho'. Dois anos depois, afastou-se para assumir uma cátedra no Curso de Engenheiros-Arquitetos da Escola Politécnica, então já jurisdicionada à Universidade de São Paulo. Esse foi o quadro docente básico das disciplinas específicas do Curso ao longo dos seus primeiros 25 anos. No lustro que vai de 1942 até a criação da Faculdade de Arquitetura (1947), novos nomes passaram a fazer parte do corpo docente do Curso: Elisiário da Cunha Bahiana (em 1943, para as disciplinas 'Arquitetura Paisagista', 'Organização do Trabalho', depois 'Prática Profissional'), Pedro Corona (em 1946, para as disciplinas 'Modelagem' e 'Desenho Artístico') e Ruy Martins Ferreira (em 1946, para as disciplinas 'História da Arte', 'Arquitetura no Brasil' e 'Composições Decorativas').

No tronco comum com o Curso de Engenharia Civil, atuaram inúmeros professores catedráticos, contratados e assistentes, alguns de notória projeção profissional. Desse grupo, no período que vai de 1917 a 1947, são inevitáveis as seguintes menções nominais: Alexandre Maurício Orecchia, Álvaro Mendonça, Américo da Graça Martins, Antenor Pinto da Silveira, Antonio Luiz Ippólito, Arthur Motta, Domingos Nolasco de Almeida, Edison de Aguiar Souza, Elato Silva, Evaristo Valladares Costa, Henrique Neves Lefèvre, Humberto Fonseca, Luiz de Castro Sette, Lysandro Pereira da Silva, Odair Grillo, Paulo Sampaio Wilken, Serafim Orlandi, Sergio Sonnino, Ulysses Aguiar de Souza e Ulysses Belluzzo (ANUÁRIO, 1949, p. 131-133).

O que ensinavam esses docentes? Que orientação recebiam do Deão (depois Diretor) do Curso de Arquitetura, formador de Engenheiros-Arquitetos? Quais eram as estratégias que adotavam para ministrar suas disciplinas? Como se estruturavam as matrizes curriculares do Curso? Quais eram os conteúdos dos programas? Qual o perfil da bibliografia adotada? Encontravam-se exemplares dessa bibliografia disponíveis na biblioteca? Com que frequência
Na página anterior:

Estação Júlio Prestes, São Paulo, projetada pelo Arquiteto Christiano Stockler das Neves e pelo Engenheiro Samuel das Neves em 1925 e concluída 13 anos depois, em 1938. Com 25 mil m² $^{2}$ a construção foi inspirada nos terminais ferroviários norte-americanos, tais como a Grand Central Station (1903), cujo nome foi atualizado para Grand Central Terminal (1913), e a Pennsylvania Station (Penn Station, 1910), com o propósito de abrigar a principal estação da então Estrada de Ferro Sorocabana. Sofreu importante intervenção em 1999, passando a abrigar além das instalações da estação ferroviária da Linha 8 - Diamante, da CPTM, a sede da Secretaria de Cultura de São Paulo e a Sala São Paulo, casa de concertos da Orquestra Sinfônica do estado de São Paulo (Osesp), projeto de autoria do Arquiteto Nelson Dupré (Mackenzie, 1973). 


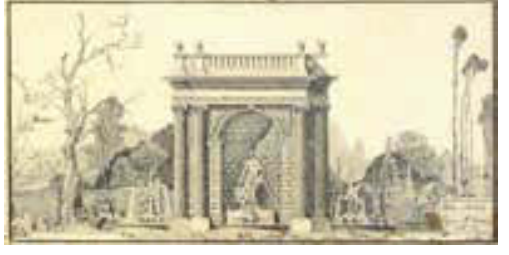

Ca.1947. Projeto de uma fonte. Autoria do Engenheiro Civil e Arquiteto Elgson Ribeiro Gomes (Mackenzie, 1958).

7. O Centro Histórico e Cultural Mackenzie (CHCM) conta com acervo semelhante, eventualmente mais amplo. A referência ao arquivo históricodocumental da Escola de Engenharia decorre de terem sido buscados nesse acervo os elementos documentais aqui referidos e utilizados. eram atualizadas as indicações bibliográficas? Qual era a infraestrutura de que dispunham os docentes? Tinham ateliês, oficinas e laboratórios adequados? Que tipo de interação com escritórios individuais e empresas construtoras era mantida? Quem eram os alunos - seu perfil socioeconômico - que procuravam o Curso de Engenheiros-Arquitetos da Escola de Engenharia Mackenzie College (até 1934), ou simplesmente Escola de Engenharia Mackenzie (após 1934)? Manteve-se esse título de Engenheiro-Arquiteto fixo ao longo do tempo ou houve mudanças na denominação do Curso e do respectivo título? Teve sempre o Curso a duração de cinco anos? Evidentemente, não temos condições de fornecer respostas completas para todas essas questões, pelas próprias limitações impostas ao texto. Recorremos, contudo, a algumas referências pontuais que poderão fornecer traços desse instigante quadro.

Com relação aos conteúdos programáticos, o roteiro de pesquisa passa pelo arquivo histórico-documental da Escola de Engenharia da Universidade Presbiteriana Mackenzie, ${ }^{7}$ que dispõe de volumes encadernados contendo valiosas informações, dentre as quais as ementas das matérias lecionadas nos cursos do Mackenzie College, desde 1905, assim como os programas analíticos de todas as disciplinas ministradas na Escola de Engenharia, a partir de 1927, com pequenos lapsos temporais (ANUÁRIO, 1949). Essas fontes podem responder a parte dos quesitos propostos no parágrafo anterior, especialmente se as grades curriculares e os conteúdos programáticos forem dispostos em sequência cronológica, do que se poderá observar sua evolução ou eventual estagnação, comparativamente às espirais do desenvolvimento sociocultural e tecnológico da época.

A título de ilustração, verifica-se que o programa da disciplina 'História da Arquitetura', de 1927, não continha tópico relativo à Arquitetura Contemporânea, encerrando a sequência programática com Arquitetura Tradicional do Brasil (ANUÁRIO, 1949, p. 266). Já no programa da cadeira de 'Arquitetura Analítica' (que substituiu a disciplina 'História da Arquitetura'), editado em 1941, os últimos dois tópicos dizem respeito à Arquitetura Colonial no Brasil e à Arquitetura Contemporânea (ANUÁRIO, 1941, p. 361-362). Para quem se debruça sobre o tema, essa discreta mudança traduz mais que uma atualização programática. É reveladora de um quadro de tensões que excitavam as entranhas do Curso e de uma tendência irreversível de acolhimento de novos paradigmas para a Arquitetura. Esses vetores tinham direção e sentido convergentes para a figura ímpar do fundador-diretor do Curso, o Arquiteto Christiano Stockler das Neves.

Outro registro capaz de elucidar a própria dinâmica do Curso que formava Engenheiros-Arquitetos encontra-se no preâmbulo do programa da cadeira de 'Pequenas Composições de Arquitetura', editado em 1941, de responsabilidade de Christiano Stockler das Neves, eventualmente ministrada por um dos seus assistentes. Cabia aos alunos a elaboração de um projeto temático, que deveria ser apresentado em duas fases, respectivamente, o esboço e o lançamento da ideia em uma primeira sessão e o desenvolvimento do projeto a partir desse esboço preliminar, em sessões seguintes. Esses procedimentos submetiam-se à norma abaixo, em que, à parte dos conceitos inseridos nas entrelinhas, declara-se de forma sinuosa que a autonomia do aluno devia ser compensada pela sua competência: 
A crítica dos esboços feita pelo professor provocará o debate, a exposição de motivos e esclarecimentos, dando a oportunidade a este de medir os valores individuais, orientar os desequilíbrios de composição e verificar as tendências pessoais aproveitáveis. (ANUÁRIO, 1941, p. 354).

A identificação das características do Curso de Arquitetura oferece um largo leque de possibilidades. Poderíamos destacar referências alusivas à célebre controvérsia entre a tendência "clássica" (tradicional, conservadora), defendida com veemência e competência por Christiano Stockler das Neves, e a tendência "modernista" que se impunha por força dos movimentos sincrônicos que se multiplicavam pelo mundo afora, e de modo peculiar, no Brasil, afetando significativamente as manifestações da arte, da música, da literatura e da Arquitetura. Não o faremos neste exíguo espaço, pois teríamos que ser superficiais na análise desse embate que transcende as questões acadêmicas. ${ }^{8}$

Retornemos para as características marcantes do Curso, abordando aqui os trabaIhos de conclusão do ciclo acadêmico, de natureza interdisciplinar e nível semiprofissional, denominados "Projectos-These", dos tempos do Mackenzie College.

\section{Os "Projectos-These" do Mackenzie College}

Seguindo modelo norte-americano, a Escola de Engenharia Mackenzie College estabelecera, desde a sua origem em 1896, a exigência da elaboração de trabalho de conclusão de curso, denominado "Projecto-These", cuja apresentação final era feita perante a Congregação da Escola, em sessão pública, encontrando-se presente o Inspetor da Universidade do Estado de Nova York, além de convidados especiais. ${ }^{9}$ Com a implantação do Curso de Arquitetura em 1917, esse requisito formal foi preservado, constando dos prontuários individuais dos concluintes os títulos das suas produções acadêmicas, que tinham cunho semiprofissional. Houve situações atípicas, em que os candidatos não obtiveram aprovação, e outras, em que os projetos foram desenvolvidos em duplas de alunos, em função do volume e da abrangência desses trabalhos. Aos reprovados, propunha-se nova sessão pública, que se realizava, às vezes, somente um ano depois, uma vez que a presença do representante de Nova York era condição obrigatória, até 30 de junho de 1927. Nessa data, foi concedida autonomia acadêmica ao Mackenzie College em relação à University of the State of New York (USNY), uma espécie de autarquia fiscalizadora do ensino superior, que impunha os paradigmas acadêmicos e assegurava a qualidade dos cursos vinculados, possibilitando que os diplomas de graduação tivessem reconhecimento automático nos Estados Unidos, permitindo-se também aos seus portadores o exercício profissional naquele país do Norte.

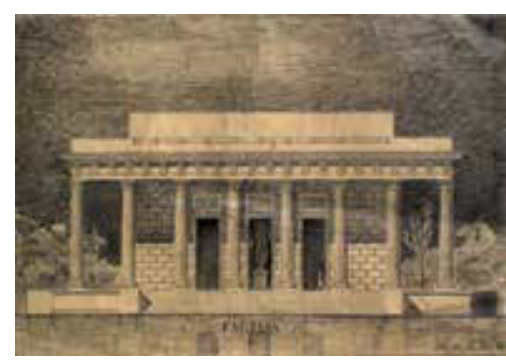

Ca.1947. Projeto para uma fachada. Autoria do Engenheiro Civil e Arquiteto Elgson Ribeiro Gomes (Mackenzie, 1958).

8. Ver, dentre outros autores e textos, Abrunhosa (2016)

9. Depois de 1927, a presença do Inspetor (representante) designado pela Universidade do Estado de Nova York foi substituída pela do Inspetor Federal nomeado pelo Ministério da Educação e Saúde para supervisionar a Escola de Engenharia Mackenzie. 

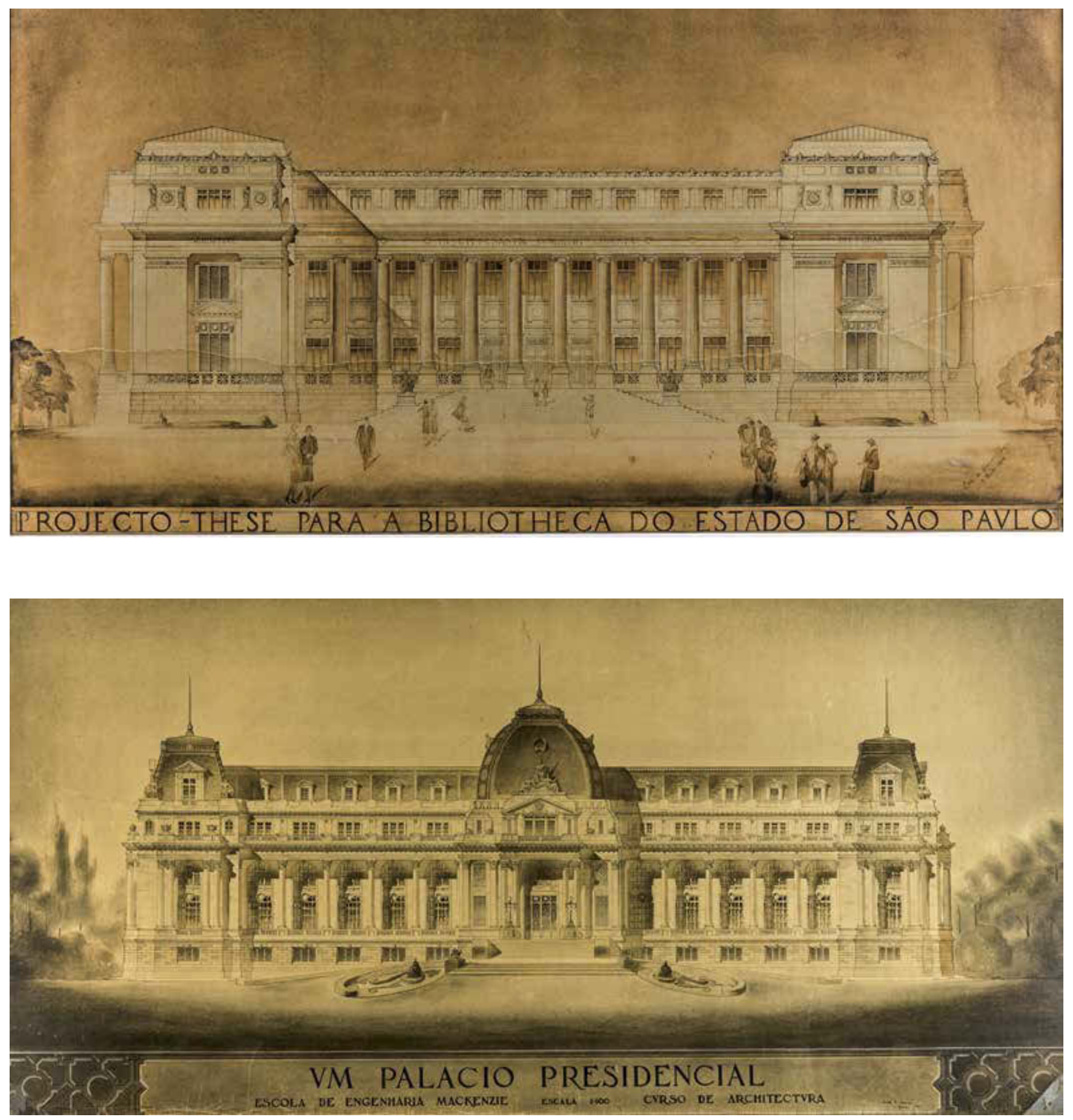
A equiparação dos cursos da Escola de Engenharia Mackenzie College aos congêneres nacionais, formalizada pelo Decreto Legislativo no 4.659-A, de 19 de janeiro de 1923, tornara, de fato, dispensável a subordinação acadêmica a Nova York. Esse desfecho demorou para se consumar e custou à Escola de Engenharia abrir mão dos referenciais norte-americanos, para adotar os programas da Escola Nacional de Engenharia e da Escola Nacional de Belas Artes (ANUÁRIO, 1942, p. 34). Esta última deu origem (em 1945) à Faculdade Nacional de Arquitetura - a primeira do país com a designação 'Arquitetura' -, hoje Faculdade de Arquitetura e Urbanismo da Universidade Federal do Rio de Janeiro. Por volta de 1935, com a completa equiparação dos seus cursos aos congêneres nacionais, a Escola de Engenharia Mackenzie deixou de exigir dos seus formandos a realização dos chamados "Projectos-These", restando algumas opções individuais pelo chamado "Diploma Americano", que ainda vigoraram, nesses casos excepcionais, até 1939.

Os Anuários da Escola de Engenharia Mackenzie editados a partir de 1934 publicam a relação dos títulos dos Projetos-Tese apresentados, enquanto os Livros de Atas da Congregação consignam as sessões públicas em que esses trabalhos eram defendidos, constando, em alguns casos, o próprio teor das arguições dos examinadores e os termos das respostas oferecidas pelos formandos. Destacamos, a seguir, os títulos das produções dos Engenheiros-Arquitetos identificados nos registros disponíveis, seus autores e o ano de conclusão, desde a primeira turma (1919) até quando a exigência deixou de ser imposta (1935),10 em decorrência das mudanças estruturais por que passou a Escola de Engenharia para se adaptar à legislação educacional brasileira (ANUÁRIO, 1934; 1955). Por motivos que não conseguimos apurar, dois nomes da turma de 1930 e outros sete, da turma de 1932, não tiveram os títulos dos seus Projetos-Tese publicados nos Anuários, nem as respectivas Atas foram localizadas. Deixam, portanto, de constar do Quadro 1, abaixo, que é composto de 47 nomes de Engenheiros-Arquitetos do antigo Mackenzie College:

\section{Quadro 1 - "Projectos-These" dos Engenheiros-Arquitetos, de 1919 a 1934 (continua).}

\begin{tabular}{lll} 
Título & Autor & Ano \\
\hline Uma Embaixada & Waldemar Kneese Ferreira & 1919 \\
\hline Escola Paulista de Belas Artes & Antonio Gomes Barreiros & 1920 \\
\hline $\begin{array}{l}\text { Pavilhão da Itália na Exposição do Centenário da } \\
\text { Independência Brasileira }\end{array}$ & Caetano Carnicelli & 1920 \\
\hline Palácio de Justiça do Estado do Paraná & Romeu do Amaral & 1920 \\
\hline Projeto de um Palácio de Justiça & Antonio Gallo Ferrigno & 1922 \\
\hline Projeto de um Museu de Belas Artes & José do Amaral Neddermeyer & 1922 \\
\hline Projeto de um Conservatório de Música para São Paulo & Renato Ribeiro de Aguiar & 1922 \\
\hline Projeto do Cine-Teatro de Jaú & Armênio de Lima Goes & 1923 \\
\hline Projeto do Teatro Municipal de Santos & Salomão Rosa & 1923 \\
\hline Projeto do Museu de História Natural de São Paulo & Francisco de Paula Silveira & 1924 \\
\hline Projeto de um Centro das Artes em São Paulo & João dos Santos Filho & 1924 \\
\hline Instituto de Ciências e Letras para a Cidade de São Paulo & Antonio Cassese & 1925 \\
\hline $\begin{array}{l}\text { Nova Estação da S. Paulo Railway, no Brás, com o Plano } \\
\text { das Linhas Elevadas }\end{array}$ & Francisco José Esteves Kosuta & 1925
\end{tabular}

Na página anterior:

Projecto-These para a Biblioteca do estado de São Paulo. Autoria da Engenheira-Arquiteta Zilda Sampaio Perrone, primeira mulher a se diplomar no Curso de Arquitetura da Escola de Engenharia do Mackenzie College (Mackenzie, 1929).

Projecto-These - VM Palácio Presidencial, de autoria do Engenheiro-Arquiteto Walter Saraiva Kneese, então discente do Curso de Arquitetura da Escola de Engenharia do Mackenzie College.

10. O chamado "Curso Americano" tinha exigências similares às estabelecidas nos regulamentos do curso "nacional", acrescidas do seguinte: média das notas para habilitação, 60; 85\% de frequência obrigatória às aulas teóricas e práticas; Projecto-These no final do curso (ANUÁRIO, 1938, p. 21-23) 
Quadro 1 - "Projectos-These" dos Engenheiros-Arquitetos, de 1919 a 1934 (continuação).

Título

Projeto de uma Casa de Apartamentos em Concreto Armado

\begin{tabular}{l} 
Paço Municipal para a Cidade de Campinas \\
\hline Projeto de uma Residência Diplomática para o Ministro
\end{tabular}

Brasileiro junto à Liga das Nações

Projeto de um Clube para a Cidade de Ribeirão Preto

Projeto do novo Paço Municipal de Taubaté

Projeto do Novo Palácio do Governo de São Paulo

Projeto de um Cine-Teatro para São Paulo

Projeto do Ginásio do Estado

Projeto de um Asilo para Velhos

Projeto de uma Escola de Arquitetura para São Paulo

Projeto de um Congresso do Estado para São Paulo

Projeto de um Estádio

Projeto de uma Academia de Belas Artes

Projeto da Escola de Farmácia e Odontologia de Araraquara

Projeto de um Paço Municipal para a Cidade de Santos

Projeto de um Auditório para a Cidade de Campinas

Projeto de um Edifício Comercial para a Cidade de São Paulo

Projeto de um Prédio para Agência de Banco em Guaratinguetá

Projeto de um Banco para a Cidade de São Paulo

Projeto de um Aeroporto para a Cidade de São Paulo

Projeto de uma Biblioteca para a Cidade de São Paulo

Projeto de um Panteão Nacional

Projeto para o novo Viaduto do Chá

Projeto de Correios e Telégrafos para a Cidade de Campinas

Projeto de um novo Hipódromo para São Paulo

Projeto de uma Escola de Belas Artes para a Cidade de São Paulo

Projeto de um Clube para a Cidade de Caxias do Sul

Projeto de um Clube para a Cidade de Caxias do Sul

Projeto de um Colégio Evangélico para a Cidade de Ourinhos

Projeto de um Aeroporto

Projeto de uma Policlínica para São Paulo

Projeto de uma Faculdade de Ciências para São Paulo

Projeto de uma "Santa Casa"

Projeto de Biblioteca para a Universidade de São Paulo

Projeto de um Palácio Presidencial

Fontes: ANUÁRIO (1934, p. 120-135) e ANUÁRIO (1935, p. 171-172).

52
Autor

Ano

Guilherme Corazza

Henrique Franzoni

Ítalo Martinelli

Alexandre Cesar Cococci

José Bastos Silva

Miguel Próta

Álvaro David do Valle

Francisco Souza Rocha Jr.

Joaquim Marques Ladeira

José Dias da Gama

Oswaldo Barreto Robinson

Plínio Botelho do Amaral

Renato de Guglielmo

Ruy Fernandes Seixas

Alcides Xande

Luiz Del Nero

Raul Freire de Mattos Barretto

1928

Vicente Del Monaco

1928

Fernando Alberto Gama Rodrigues 1929

Max Hans Förtner

Zilda de Almeida Sampaio

Alfredo Cecílio Lopes

Antonio Tadeu Giuzio

Armando Ciampolin

Américo Capua

Décio da Silva Pacheco

José Perroni Jr.

Alberto Schirato

1931

Carlos Amélio Botti

1931

Eduardo A. Kneese de Mello

Olívia Barros do Amaral

Vicente Nigro Jr.

1931

Francisco José Dale Caiuby

Walter Saraiva Kneese

1931

1934

1934

925 925

925

926

926

926

927

927

927

1927

1927

1927

927

1928

1928

928

929

929

1929

1930

1930

930

1930

930

1930

927


A listagem apresentada presta-se a análises que este espaço não comporta. Poderia, por exemplo, ser comparada com a lista de títulos dos Projetos-Tese dos concluintes de Engenharia Civil, na mesma época e na mesma Instituição, os quais tinham dois anos de tronco comum na sua formação. Em outro contexto, fizemos essa comparação e observamos que os engenheirandos do Mackenzie, orientados por seus mestres, desenvolviam, à guisa de Projeto-Tese, projetos semiprofissionais de estruturas prediais em concreto armado, de subestações elétricas, de fundações, de obras de terra e estudos de sistemas de saneamento. Parecia claro para ambos - arquitetos e engenheiros - que suas áreas de atribuição eram de natureza complementar, ainda que a fronteira temática que divide os campos dessas duas carreiras pudesse ser tênue, em razão da existência de certas zonas de 'sombreamento'. Daí o risco, muitas vezes presente, do conflito de atribuições. No tocante ao Curso de Arquitetura, formador de engenheiros-arquitetos, esse conflito em potencial tinha tendência de se tornar mais intenso, devido às posições do seu Deão (depois Diretor) Christiano Stockler das Neves, que eram claramente favoráveis à preponderância do arquiteto sobre o engenheiro na cadeia produtiva de projeto - planejamento - construção.

Em nova digressão contextual, é o caso de perguntar: o que acontecia fora dos limites do campus de Higienópolis, com inevitáveis incidências sobre o ambiente acadêmico? Eram os Projetos-Tese dos acadêmicos do Curso de Arquitetura consentâneos com o que se passava em São Paulo e no Brasil?

Na São Paulo de Piratininga, o discurso mais eloquente de que o 'novo' chegava para superar definitivamente o 'velho' materializava-se nas artérias urbanas - mais largas e mais retilíneas - e nas expressões arquitetônicas, que titubeavam entre os paradigmas clássicos de Londres e Paris e os gabaritos norte-americanos de Nova York excitados pelos desafios da verticalidade (SOMEKH, 2014). Na dúvida, prevaleceu o eclético, o sincrético, a mistura, o retalho. No dizer de Monteiro Lobato, um verdadeiro "carnaval arquitetônico". Para colocar de pé os edifícios, preferiu-se a tecnologia do concreto armado, que proporcionou ao Brasil recordes de arrojo na altura e na esbelteza, enquanto em outras latitudes do planeta as soluções estruturais elegiam perfis metálicos, laminados ou fundidos, rebitados ou parafusados. Afinal, tínhamos a pedra, a areia, a madeira, a mão de obra barata... faltava apenas o cimento: até 1926, este vinha da Europa como se fosse uma especiaria das Índias.

E para escalar esses novos arranha-céus, nada melhor que os elevadores importados do hemisfério norte, com manuais redigidos em inglês, francês e alemão. Afinal, éramos cosmopolitas... São dessa geração: o 'Edifício Sampaio Moreira' de autoria de Christiano Stockler das Neves e Samuel das Neves, com 14 andares, inaugurado em 1924, e que ostentou por algum tempo o título de "primeiro arranha-céu de São Paulo", e logo, chegou a vez do grandioso Edifício Martinelli idealizado pelo empresário italiano Giuseppe Martinelli (1870-1946), inaugurado incompleto em 1929, e que chegou a 30 andares, contados seus subsolos e porões. Até o ano de 1947, o 'Edifício Martinelli' tornou-se o maior arranha-céu do país e o mais alto da 
Diploma de Arquiteto de Galiano

Ciampaglia (Mackenzie, 1939).

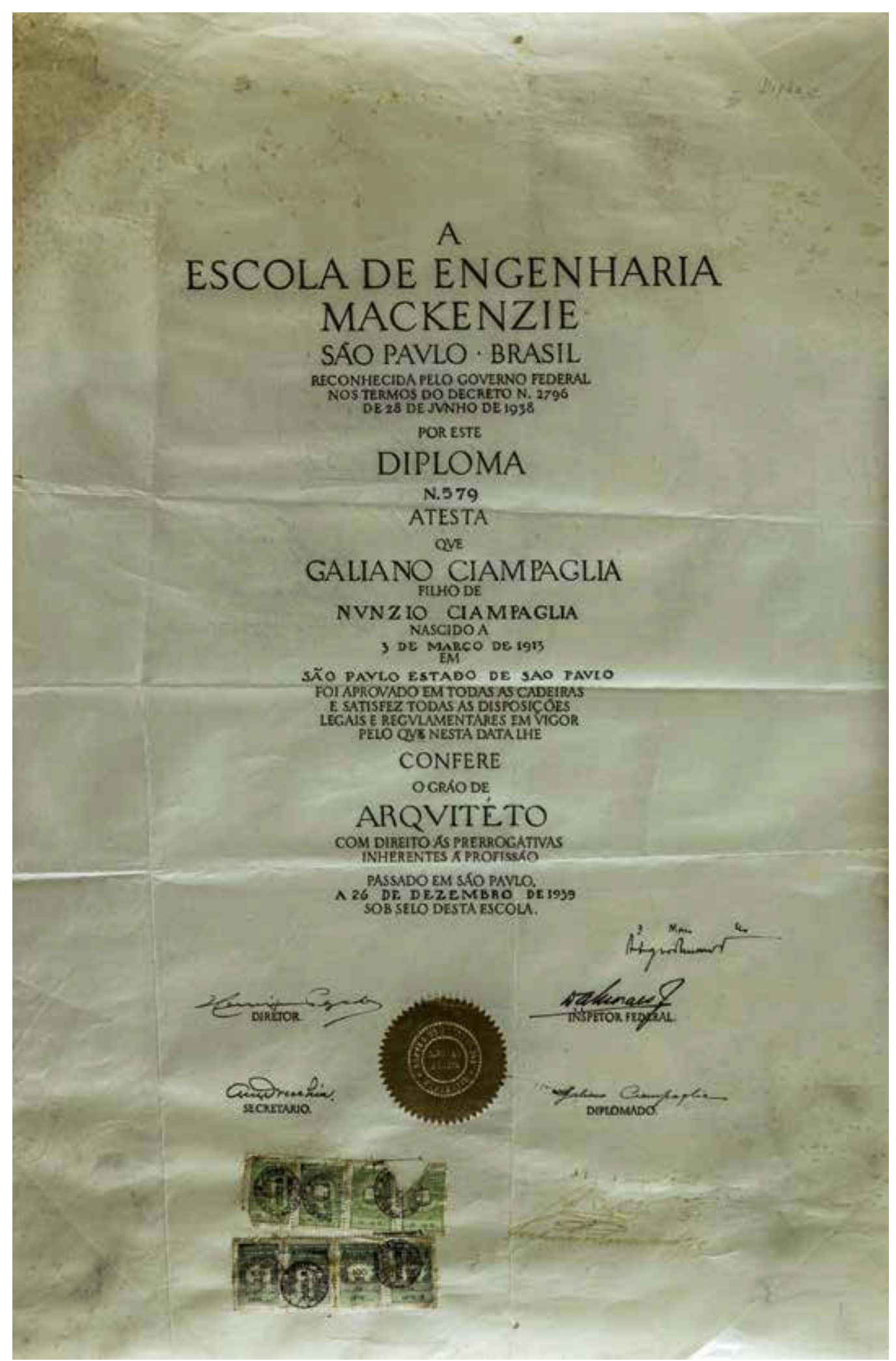


América Latina. De suas estonteantes alturas foram disparadas baterias antiaéreas contra aviões do Governo Provisório de Vargas, por ocasião do Movimento Constitucionalista de 1932. Muita pretensão, certamente, mas ao menos a bravata teve o sabor da inovação tecnológica. Fechemos a digressão, para não perder o fluxo dos acontecimentos no quadrilátero de Higienópolis.

\section{Sobre os primeiros diplomas de "Arquiteto" em São Paulo}

Curiosamente, o Curso de Engenheiros-Arquitetos implantado em 1917 subordinou-se, nas reformas estruturais por que passou a Escola de Engenharia na década de 1930, a uma nova denominação tópica, que, se não Ihe modificou a identidade, alterou-lhe as feições. Essa transfiguração não foi espontânea, mas ocorreu por força de imposições da legislação. Com efeito, em 1933, foi atribuída ao Curso de Engenheiros-Arquitetos a denominação de 'Belas Artes', com duas subdivisões: 'Arquitetura' e 'Pintura e Escultura'. Quanto às durações dos cursos da Escola de Engenharia, ficaram, então, assim definidas: Cursos de Engenharia (Civil, Elétrica e Industrial) - cinco anos; Curso de Arquitetura - seis anos; Curso de Pintura e Escultura - quatro anos. A propósito das mudanças impostas ao Curso de Arquitetura, seu Diretor manifestou total desagrado, entendendo que havia repetição desnecessária de assuntos e disciplinas, e que certas cadeiras poderiam até ser dispensadas, num esforço de racionalização:

Parece-nos, pois, que a reforma de ensino da Arquitetura não correspondeu aos ensinamentos dos povos mais adiantados e às necessidades do nosso meio. Não nos parece justo que a nossa mocidade se sacrifique durante seis longos anos numa escola, quando poderia aprender a mesma coisa em quatro. Representa isso maiores despesas para os estudantes sem que no futuro colham maiores resultados na sua profissão. Tal reforma lança o desânimo nos alunos e nos professores. (UNIVERSIDADE PRESBITERIANA MACKENZIE, 1933).

Consta dos registros que, em 1936, o curso de 'Pintura e Escultura' ainda não estava funcionando (ANUÁRIO, 1936, p. 51). Nas edições seguintes do Anuário da Escola de Engenharia, existe menção dos programas desse Curso, mas nenhuma referência confirma sua efetiva implantação. Cabe ressaltar que essas mudanças tiveram em vista atender tanto à legislação educacional, que impunha o paradigma da Faculdade Nacional de Belas Artes (Rio de Janeiro), como também à regulamentação da profissão dos engenheiros, arquitetos e agrimensores, datada de 11 de dezembro de 1933, que deu origem ao sistema Confea/ Crea. Para esse desfecho, foram relevantes as participações de lideranças profissionais e entidades de classe, destacando-se entre os engenheiros-arquitetos de São Paulo as respeitáveis figuras de Alexandre Albuquerque e Christiano Stockler das Neves, ainda que guardassem entre si diferenças abissais com relação aos conceitos que deveriam nortear a prática e o ensino da Arquitetura. A Escola de Engenharia Mackenzie não deixou sem registro essa efeméride: 


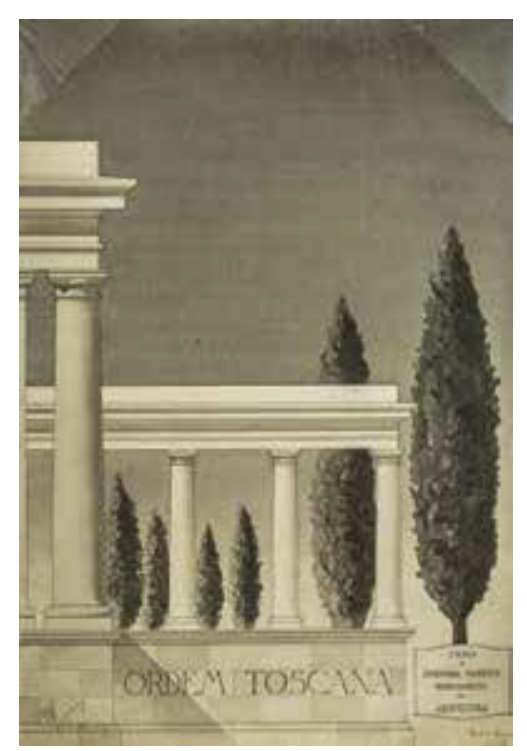

Ca. 1932. Exercício de projeto (disciplinas Grandes Composições de Arquitetura e Pequenas Composições de Arquitetura), utilizando a Ordem Toscana, de autoria do Engenheiro-Arquiteto Walter Saraiva Kneese, então discente do Curso de Arquitetura da Escola de Engenharia do Mackenzie College.
Foi, afinal, tornada realidade a regulamentação das profissões de engenheiro, arquiteto e agrimensor, por várias vezes tentada sem alcançar o êxito desejado, com a instalação dos conselhos federal e regionais. Poderão agora as escolas de engenharia e arquitetura esclarecer, altivamente, aos seus alunos que, a profissão por eles abraçada é respeitada e inacessível aos que não buscaram os necessários conhecimentos nas escolas superiores, não se submetendo aos estudos exaustivos, que bem merecem uma justa recompensa na vida prática. (ANUÁRIO, 1936, p. 51).

Um fato praticamente desconhecido da historiografia da Arquitetura paulista é que no contexto das adequações curriculares que a Escola de Engenharia Mackenzie promoveu a partir de 1933, a subdivisão de 'Arquitetura' do novo curso de 'Belas Artes', com seis anos de duração, deu ensejo à inédita atribuição do título de 'Arquiteto' aos graduados a partir do ano de 1939. Para esse esclarecimento, muito contribuíram as recentes pesquisas realizadas por Fernanda Ciampaglia, tornadas públicas tanto na forma de artigo como na configuração de sua Dissertação de Mestrado, na FAU-USP em 2012. Desse último documento acadêmico, destacamos o seguinte trecho que, embora longo, é emblemático:

\footnotetext{
Reexaminados, os arquivos e anuários confirmaram o cumprimento de seis anos apenas para as turmas que ingressaram na escola a partir de 1934 e cujas colações de grau fazem distinção entre "arquitetos" e "engenheiros". É bem verdade que diante da paulatina adequação a que esteve sujeito o curriculum, o diploma de "arquiteto" ou de "engenheiro-arquiteto" não é relevante na qualidade do profissional formado no período da transição da Escola de Engenharia Mackenzie para a Faculdade de Arquitetura Mackenzie. A relevância estaria na própria historiografia da arquitetura paulista, que passaria a creditar à Escola de Engenharia Mackenzie esse pioneirismo, já em 1939. Na Escola Politécnica, o curso de "engenheiro-arquiteto" foi mantido até 1954. (CIAMPAGLIA, 2012, p. 37).
}

Esses esclarecimentos contribuem para o completo entendimento da transição ocorrida no meio da década de 1930, em que os últimos títulos de 'Engenheiro Arquiteto' do Mackenzie foram atribuídos, em 1937, aos concluintes (de cinco anos) Manoel Carlos G. de Soutello e Maurício dos Santos Cruz, enquanto no ano de 1938 não foi realizada cerimônia de formatura, devido ao 'prolongamento' do Curso para seis anos, desaguando na formatura da primeira turma de 'Arquitetos', em 1939. Nesse ano, na data de 26 de dezembro, no Theatro Municipal de São Paulo, foram conferidos os primeiros diplomas de 'Arquiteto', na história da educação superior em São Paulo, aos seguintes mackenzistas: Galiano Ciampaglia (diploma no 579), Igor Sresnewsky (diploma no 580), Manoel Amadeu G. De Soutello (diploma no 581), Miguel Forte (diploma no 582) e Sophie Elma M. Capps (diploma no 583) - quatro homens, uma mulher - todos pioneiros! (CIAMPAGLIA, 2012, p. 37; ANUÁRIO, 1939, p. 54-55). 
A duração de seis anos para o Curso de Arquitetura foi mantida até 1946, quando retornou para cinco anos. Cada ano se constituía de dois semestres letivos denominados "períodos", respectivamente, "de segunda-feira entre 7 e 13 de fevereiro, até sábado entre 10 e 17 de junho, e o segundo, de segunda-feira entre 4 e 10 de julho, até sábado entre 5 e 11 de novembro" (ANUÁRIO, 1934, p. 161). As jornadas diárias ocupavam manhã e tarde, respectivamente, das $7 \mathrm{~h} 30$ às $11 \mathrm{~h} 05$ e das $12 \mathrm{~h} 45$ às 15h15, com extensão até 17 horas, quando necessário. As aulas teóricas eram ministradas de preferência no período da manhã e os trabalhos de laboratório, desenho e demais exercícios práticos, no período da tarde. Ao contrário dos cursos de Engenharia, que considerava a frequência às aulas teóricas facultativa, "no Curso de Arquitetura, será obrigatória a frequência às preleções, às aulas práticas, aos trabalhos escolares, às excursões e aos demais exercícios" (ANUÁRIO, 1934, p. 161-162). Onde se realizavam as "preleções" teóricas e as aulas práticas? Havia salas-ambiente e edificações exclusivas? Façamos uma ligeira referência a isso.

\section{Instalações do Curso de Arquitetura em busca de um edifício-sede}

Apesar do pequeno contingente numérico, a questão das instalações para a parte específica do Curso de Arquitetura era crucial para o seu desenvolvimento. Havia somente dois ambientes exclusivos, considerados 'laboratórios' do Curso: 'Sala de Modelagem' e 'Museu de Arquitetura'. Em relatório especial elaborado pela Inspeção Federal, no ano de 1936, época em que se pleiteava o restabelecimento da validade dos diplomas da Escola de Engenharia, constou o seguinte registro, no mínimo, desafiador:

\footnotetext{
Julgamos que a secção de Arquitetura não está instalada de maneira satisfatória para o ensino prático de certas partes do curso, necessitando uma melhor aparelhagem em certas cadeiras, e mesmo melhor salas para o funcionamento das aulas. Informou-nos a direção da escola que já está pronto o projeto de construção de novo prédio para o curso de Arquitetura, podendo assim em pouco tempo achar-se este curso tão bem instalado como os de Engenharia Civil, Eletricidade e Industrial. (ANUÁRIO, 1936, p. 119)
}

De fato, na década de 1930, todas as aulas teóricas e de projeto vinham sendo ministradas no 'Edifício Couto de Magalhães', cujo lançamento da pedra fundamental ocorrera em 4 de julho de 1885. Prédio mais antigo em funcionamento no campus de Higienópolis e várias vezes reformado, contava com dois andares adaptados às necessidades do Curso de Arquitetura, totalizando $200 \mathrm{~m}^{2}$ de área distribuída em sete pequenas salas (ANUÁRIO, 1936, p. 137). Ainda em 1938, registrava-se que era nesse Curso de Arquitetura que mais se fazia sentir a falta de materiais de apoio, tais como modelos de gesso, slides para projeção e "uma biblioteca de livros de arquitetura" (ANUÁRIO, 1938, p. 24). Deficiências desse tipo conviveram com aquisições e melhorias que, aos poucos, foram proporcionando condições favoráveis à consolidação do Curso.

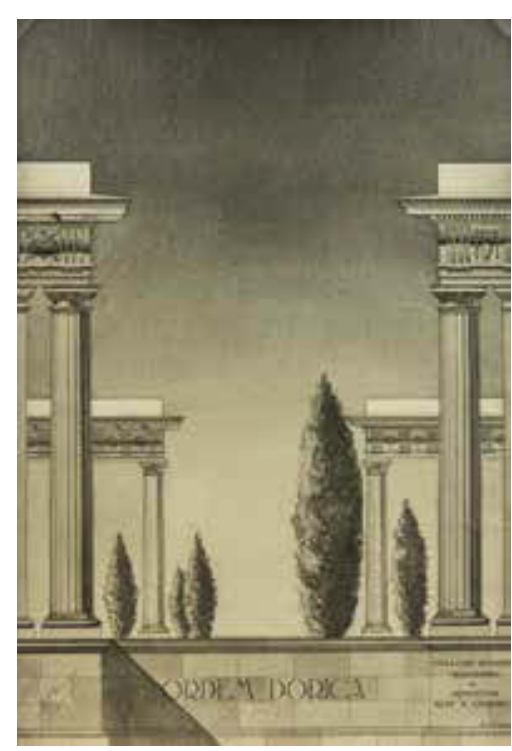

Ca. 1932. Exercício de Projeto (à época, disciplinas Grandes Composições de Arquitetura e Pequenas Composições de Arquitetura), utilizando a Ordem Dórica. Autoria do Engenheiro-Arquiteto Walter Saraiva Kneese, então discente do Curso de Arquitetura da Escola de Engenharia do Mackenzie College. 
s/d. À esquerda, o Edifício Couto de

Magalhães, que a partir de 1956 cedeu

lugar ao Edifício Christiano Stockler das

Neves, atual sede da FAU-Mackenzie.

Os dois edifícios à direita compõem

a Escola de Comércio. Também vê-se

a herma onde hoje é o bosque que

fica em frente à FAU-Mackenzie: uma

homenagem ao Dr. Horace Lane,

presidente do Instituto Presbiteriano

Mackenzie entre os anos 1885-1912.

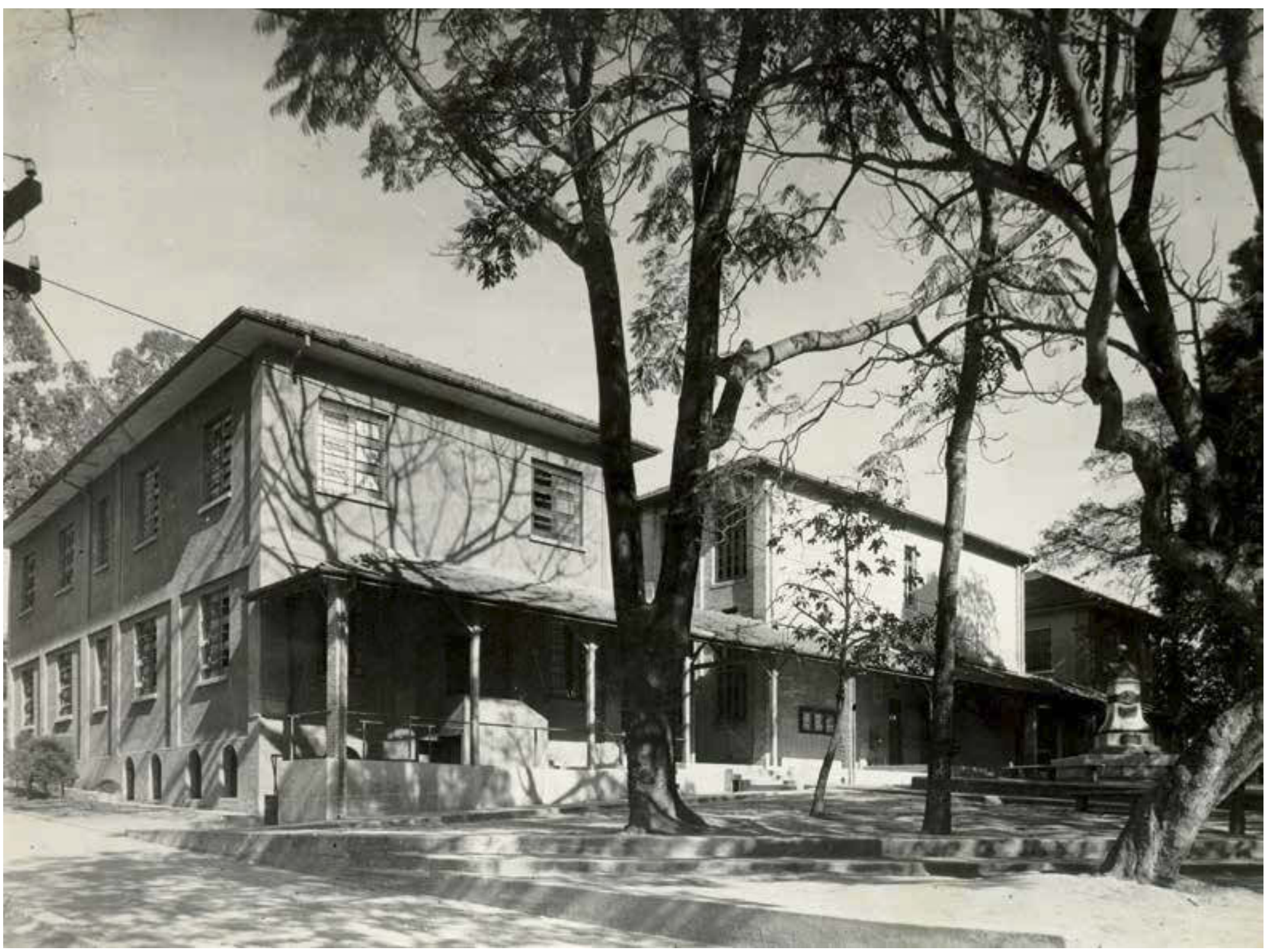


A construção do "Edifício de Química, que servirá para o Curso de Engenheiros Industriais, para o Curso de Química da Escola Técnica e para a futura Escola Superior de Química" (ANUÁRIO, 1943, p. 37), desencadeou remanejamentos que beneficiaram o Curso de Arquitetura, mas não de forma imediata nem definitiva. A propósito desse prédio, convém lembrar o inédito comparecimento do Ministro da Educação e Saúde Pública, Gustavo Capanema (1900-1985), à cerimônia de lançamento da pedra fundamental, em 24 de abril de 1943. Após a histórica visita do Imperador Pedro II, em primeiro de outubro de 1878, à Escola Americana ainda sediada na Rua de São João, essa teria sido a primeira vez que um Ministro da República esteve no Mackenzie, durante o exercício do cargo. Cabe mencionar, também, que o projeto do novo prédio foi de autoria do Arquiteto Christiano Stockler das Neves (ANUÁRIO, 1943, p. 27), ${ }^{11}$ enquanto as obras de construção foram contratadas com a empresa Pegado \& Souza, que tinha como titular principal o Engenheiro Henrique Pegado, diretor da Escola de Engenharia, de 1938 a 1952, e primeiro Reitor da Universidade Mackenzie, de 1952 a 1957. Seu sócio era o Engenheiro mackenzista Caio Luis Pereira de Souza (1906-1990), filho do ex-Presidente da República Washington Luis Pereira de Souza (1869-1957) - ambos amigos e benfeitores da instituição fundada por George W. Chamberlain (1839-1902), consolidada por Horace M. Lane e expandida por Wiliam A. Waddell. Quando da sua inauguração, às nove horas do dia 11 de dezembro de 1946, em meio às comemorações do cinquentenário da Escola de Engenharia, o prédio recebeu o nome de Edifício A. Cownley Slater (ANUÁRIO, 1946, p. 94) - uma homenagem ao fundador dos cursos técnicos do Mackenzie e dos cursos superiores de Química, inclusive o de Engenharia Química, o mais antigo do Brasil.

Em busca de melhores acomodações para o Curso de Arquitetura, que na década de 1940 crescia numericamente e ganhava prestígio, o Instituto [Presbiteriano] Mackenzie destinou o prédio do antigo Internato Masculino para a então nascente Faculdade de Arquitetura, promovendo para isso uma profunda reforma das instalações. No dia 27 de março de 1950, com a presença do Ministro da Educação e Saúde, Clemente Mariani (1900-1981), e do Reitor da Universidade de São Paulo, Miguel Reale (1910-2006), o novo 'Edifício Chamberlain' (também conhecido como 'Castelinho') foi solenemente reinaugurado. Nessa ocasião, o fundador do antigo Curso de Engenheiros-Arquitetos (1917) e naquele momento diretor da Faculdade de Arquitetura, Christiano Stockler das Neves, pronunciou-se desta forma, referindo-se às novas instalações:

Estas instalações, que ora Vossa Excelência inaugura, com tanta honra para todos nós, são a concretização de velha aspiração que sempre acalentamos e que servirão durante mais algum tempo, pois estamos certos, que muito em breve, teremos um edifício especialmente construído para nossa Faculdade, a fim de podermos corresponder ao grande número de interessados que se apresentam todos os anos ao concurso de habilitação, alguns repetidamente. É este o prêmio aos nossos modestos esforços, ao desejo de bem servir à nossa grande Pátria e à sua mocidade. (ANUÁRIO, 1950, p. 132).
11. Quando da inauguração do Edifício A. Cownley Slater, em 1946, o Prof. Antônio Valente do Couto referiu-se ao "belo projeto do insigne Arquiteto Dr. Christiano das Neves" (ANUÁRIO, 1946, p. 95). 


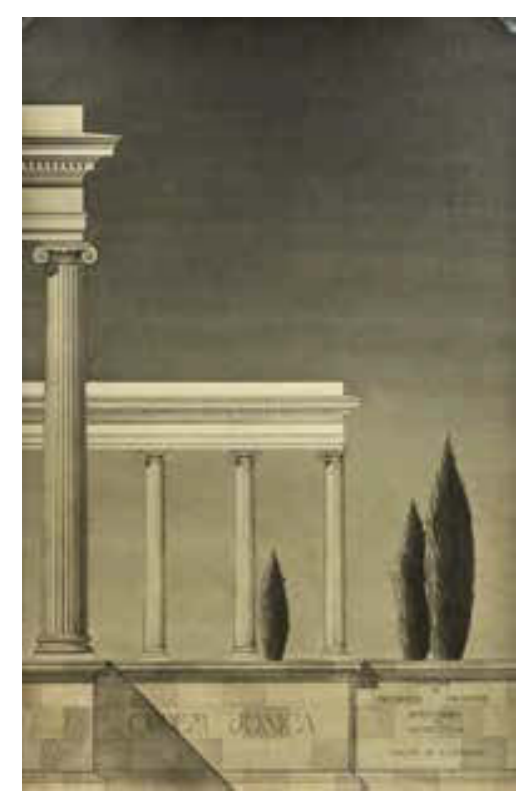

Ca. 1932. Exercício de Projeto (à época, disciplinas Grandes Composições de Arquitetura e Pequenas Composições de Arquitetura), utilizando a Ordem Jônica. Autoria do Engenheiro-Arquiteto Walter Saraiva Kneese, então discente do Curso de Arquitetura da Escola de Engenharia do Mackenzie College.
Poucos anos depois desse evento, isto é, em 1956, deu-se a demolição do antigo Edifício Couto de Magalhães, para em seu lugar ser erguido o novo prédio-sede da FAU-Mackenzie, que foi inaugurado, ainda incompleto, no ano de 1961. O projeto arquitetônico do novo prédio contou com as autorias dos Arquitetos-Professores Eduardo Corona, Takeshi Suzuki e Jun Okamoto, enquanto o projeto estrutural foi elaborado pelo engenheiro mackenzista Nelson de Barros Camargo, associado ao notável engenheiro russo Waldemar Tietz (1889-1978). Essa imponente edificação veio a ganhar o nome de Edifício Christiano Stockler das Neves - uma justa homenagem a quem dedicara 40 anos da sua vida à formação de arquitetos inovadores, críticos e empreendedores. Quanto ao prédio que vinha servindo à Faculdade de Arquitetura - Edifício Chamberlain -, passou a ser sede da Faculdade de Filosofia, Ciências e Letras, que também nascera em berço emprestado, no ano de 1947.

\section{Arquitetura \& Engenharia: rivais ou complementares?}

No contexto do antigo Mackenzie College, que foi sucedido pelo Instituto [Presbiteriano] Mackenzie, toda a trajetória do Curso de Engenheiros-Arquitetos, depois, simplesmente, Curso de Arquitetura (subdivisão do Curso de Belas Artes), preservou uma curiosa relação entre essas duas áreas, ligadas por simples hífen no título primitivo, mas colocadas frequentemente em posições de contraponto. Pelo prisma estrutural, configurava-se uma subordinação do Curso de Arquitetura à Escola de Engenharia, como uma das suas áreas de formação profissional.

Para Christiano Stockler das Neves, o próprio título de Engenheiro-Arquiteto era "redundante e exdrúxulo" [sic], levando muitos a crer que se tratava de um profissional de maiores conhecimentos que os do "simples Arquiteto". Christiano entendia que era natural a circunstância de um arquiteto necessitar da participação de engenheiros especialistas como "seus cooperadores nas obras" (REVISTA DE ENGENHARIA MACKENZIE, 1944, p. 4), em funções temporárias, enquanto que ao arquiteto caberiam as atribuições mais nobres e permanentes. Em outra oportunidade, Christiano Stockler das Neves - membro nato da Congregação da Escola de Engenharia - afirmou, sem rodeios (sic):

A architectura não é ramo da engenharia. [...] É inadimissível, portanto, que se dediquem á architectura todos aquelles que não tiveram estudos artisticos, technicos e praticos, cabedal este que só o architecto possue. O engenheiro só possue estudos technicos e praticos; para fazer architectura precisa-se do architecto. [...] O homem unicamente indicado para tudo o que se refere à edificação architectonica é o architecto. Sob sua immediata direcção devem trabalhar todos os demais profissionais. [...] O architecto surgiu antes do engenheiro; este é uma consequencia daquelle na edificação, como se póde constatar na história da architectura. (REVISTA DE ENGENHARIA MACKENZIE 1928, p. 19-20). 
Curiosamente, Christiano Stockler das Neves associava a Engenharia à tendência de prestar culto à ciência, de submeter-se ao império da tecnologia, de atuar friamente, sem alma, em busca dos melhores resultados; em outras palavras, tratava-se de uma carreira utilitarista e materialista. Esses vícios poderiam contaminar a boa Arquitetura, que deles devia se afastar em busca da verdadeira Arte, inspirada no Belo, dando espaço às criações do espírito - sem, contudo, ser retrógrada. Nas palavras do próprio criador do Curso de Engenheiros-Arquitetos, instalado na Escola de Engenharia ao longo de três décadas:

\footnotetext{
Temos resistido ao materialismo que quer destruir a maior parte das artes do desenho, a pretexto de novos materiais ou novos processos construtivos, pura técnica, que está sempre subordinada às criações do espírito. E se assim não fosse, não haveria razão para a existência de uma Faculdade de Arquitetura. As Escolas de Engenharia resolveriam o problema. [...] Não queremos dizer com isto que não acompanhemos os progressos da arquitetura da nossa época, dos novos processos construtivos e dos novos materiais empregados. (ANUÁRIO, 1950, p. 131).
}

Parte dessa visão dicotômica e assimétrica de Christiano Stockler das Neves deve ser atribuída ao seu profundo e desmesurado apreço pela profissão de arquiteto, bem como à intensidade e veemência com que sempre a defendeu, a ponto de, eventualmente, deslizar por hipérboles: "A arquitetura é o reflexo da civilização dos povos. É precursora da engenharia". Na mesma ocasião desse discurso, ele conseguiu fazer uma concessão: "As profissões do engenheiro e do arquiteto marcham juntas, reinando, hoje, perfeita harmonia entre ambas. Não são concorrentes" (ANUÁRIO, 1948, p. 214-215). Talvez coubessem aqui as ponderadas colocações do orador da turma de Engenheiros de 1951 - engenheiro Celson Ferrari - quando já havia se consumado a emancipação do Curso de Arquitetos da Escola de Engenharia, mas a formatura ainda se fazia conjuntamente: "[...] transformando em realidade as especulações da Ciência e os sonhos da Arte, concretizam, o engenheiro e o arquiteto, o Progresso em sua mais lídima acepção" (ANUÁRIO, 1951, p. 191).

Embora existisse a dúvida sobre serem (ou não) as carreiras do Engenheiro e do Arquiteto, uma "materialista" e a outra "dotada de alma", essenciais ou acessórias, complementares ou concorrentes, estava chegando o momento da subdivisão de Arquitetura do Curso de Belas Artes ganhar status de unidade autônoma. Ironicamente, o Curso de Arquitetura do Mackenzie, que nascera e crescera no berço da Escola de Engenharia, alcançava agora sua maioridade, aos 30 anos de idade, e com isso sua plena autonomia, sem dependência, sem cisão, sem conflito, sem oposição. Para isso, seriam necessárias múltiplas providências de ordem administrativa, legal e pedagógica, que culminaram com a criação da Faculdade de Arquitetura, em 1947.

\section{Nasce a Faculdade de Arquitetura (e Urbanismo) Mackenzie}

No relatório do ano de 1946, o Diretor da Escola de Engenharia Mackenzie, Henrique Pegado, fez constar pela primeira vez o tema "desmembramento do Curso de Arquitetura", ao qual dedicou extensa parte do seu texto, que iniciava assim:

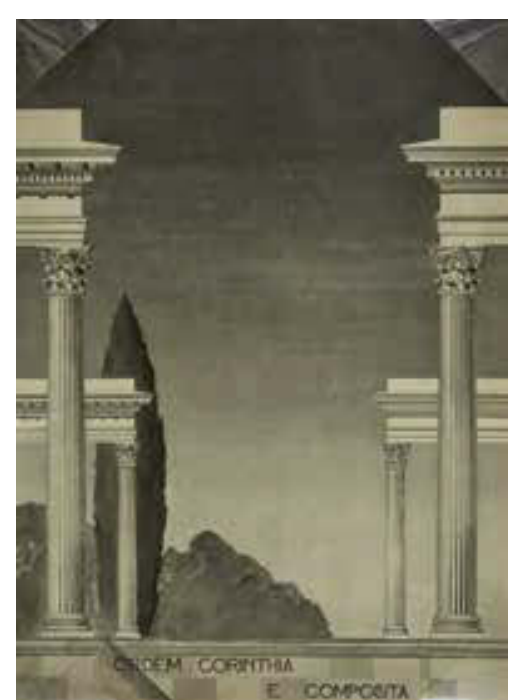

Ca. 1932. Exercício de Projeto (à época, disciplinas Grandes Composições de Arquitetura e Pequenas Composições de Arquitetura), utilizando as Ordens Corinthia e Compósita. Autoria do Engenheiro-Arquiteto Walter Saraiva Kneese, então discente do Curso de Arquitetura da Escola de Engenharia do Mackenzie College. 

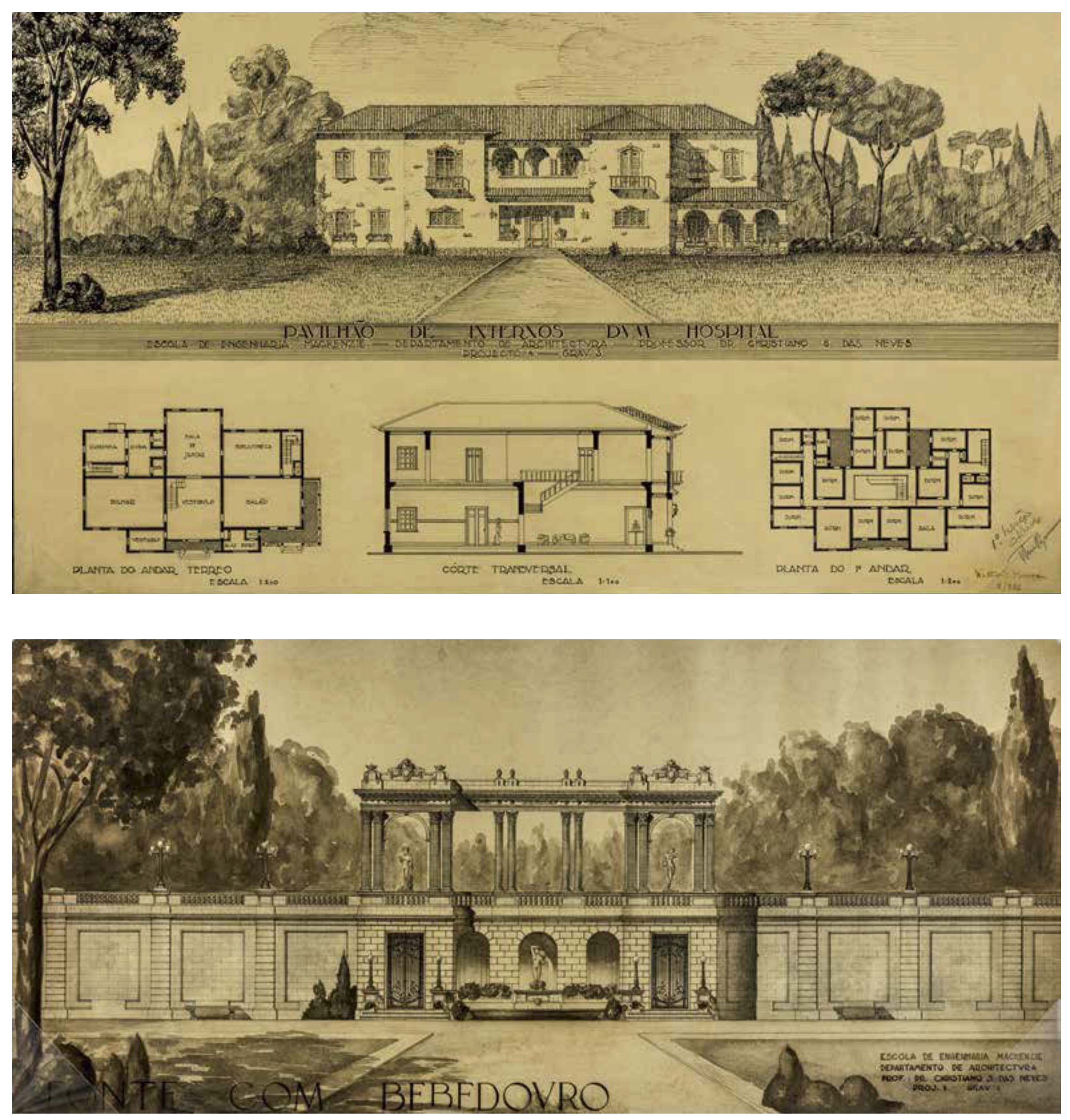
Conforme sugerimos em nosso relatório do ano passado, foi estudado o desmembramento do curso de Arquitetura da Escola de Engenharia, constituindo-se a Faculdade de Arquitetura Mackenzie. A medida foi aprovada pela Congregação da Escola de Engenharia [em 26 de abril] e pelo Conselho do Instituto Mackenzie, tendo sido designados o Diretor da Escola e o Diretor do Curso, para apresentarem um memorial justificativo, o que foi feito, a 21 de maio de 1946. Esse memorial foi aprovado [em 22 de maio] e autorizada a mesma comissão a tomar as providências necessárias para efetivar essa transformação. Foi, então, feito o estudo do Regimento Interno e, com um memorial justificativo, encaminhado o pedido, por ofício de 23 de agosto de 1946, ao Ministro da Educação e Saúde. (ANUÁRIO, 1946, p. 46-47).

No "memorial justificativo" encaminhado às autoridades educacionais da República, a Escola de Engenharia traçou ligeira retrospectiva panorâmica do Curso fundado em 1917, que a essa altura da sua evolução estava crescendo em ritmo intenso, especialmente em razão da sua redução de seis para cinco anos de duração. Expôs, também, de forma pormenorizada, o atendimento pleno do Decreto $n^{\circ} 421$, de 11 de maio de 1938, que regulava o funcionamento dos estabelecimentos de ensino superior, especialmente no seu artigo quarto, que cuidava das condições de viabilidade e efetiva necessidade do novo Curso. Tratava-se, como se pode observar, de legislação que ainda vigorava, remanescente do Estado Novo (1937-1945).

Em 21 de dezembro de 1946 - ano do cinquentenário da Escola de Engenharia o Ministro da Educação Clemente Mariani homologou o parecer favorável que o Conselho Nacional de Educação acabara de emitir, aprovando o pedido de "transformação do curso de Arquitetura Mackenzie". Constava explicitamente desse projeto que "o atual diretor do curso, Prof. Christiano S. das Neves, passará a ser interinamente o diretor da nova Faculdade, até que a Congregação seja instalada e então eleja a diretoria [...]" (ANUÁRIO, 1946, p. 49.50).

Vale a pena repetir que o crescimento numérico do Curso de Arquitetura constituía uma auspiciosa realidade. O Anuário da Escola de Engenharia de 1947 publicou que as matrículas desse Curso totalizavam 57, das quais 32 eram do primeiro ano, 17 do segundo ano, e apenas oito dos terceiro, quarto e quinto anos (ANUÁRIO, 1949, p. 115). No ano seguinte, o total de alunos subiu para 84 (ANUÁRIO, 1948, p. 197). Naquele contexto, as vagas autorizadas para o Curso de Arquitetura eram de 25 alunos por ano, mas a Escola de Engenharia solicitou aumento para 30 matrículas, o que foi autorizado pelo Conselho Nacional de Educação, em 1947. É nesse mesmo Anuário de 1947 que, relativamente ao Curso de Arquitetura, consta o registro mais significativo da década:

Em virtude do Decreto Federal no 23.275, de 7 de julho de 1947, foi o antigo curso de Arquitetura desmembrado desta Escola, transformando-se em Faculdade Autônoma, necessidade que nasceu com o interesse que esse curso vem despertando, o que se verifica pelo aumento de matrículas, reflexo, aliás, do trabalho desenvolvido pelos seus diplomados, já se fazendo sentir, em todos os setores da atividade profissional, a atuação benéfica e produtiva dos nossos arquitetos. (ANUÁRIO, 1949, p. 121).
Na página anterior

Ca. 1933. Exercício de Projeto - Pavilhão de Internos de um Hospital (à época, disciplinas Grandes Composições de Arquitetura e Pequenas Composições de Arquitetura), sob a orientação do Prof. Arquiteto Christiano Stockler das Neves. Autoria do Engenheiro-Arquiteto Walter Saraiva Kneese, então discente do Curso de Arquitetura da Escola de Engenharia do Mackenzie College.

Ca. 1932. Exercício de Projeto - Fonte com Bebedouro (à época, disciplinas Grandes Composições de Arquitetura e Pequenas Composições de Arquitetura), sob a orientação do Prof. Arquiteto Christiano Stockler das Neves. Autoria do Engenheiro-Arquiteto Walter Saraiva Kneese, então discente do Curso de Arquitetura da Escola de Engenharia do Mackenzie College. 
12. Interessante notar que a instalação da Faculdade de Arquitetura do Instituto Mackenzie e a posse de seu primeiro Diretor ocorreram no breve período de tempo em que Christiano Stockler das Neves, por nomeação do Governador Adhemar de Barros, foi prefeito da Cidade de São Paulo (de 15/3 a 28/8 de 1947).
Em sessão solene realizada a 12 de agosto de 1947, às 21 horas, na 'Sala Pandiá Calógeras' (térreo do Edifício Lane, atual Prédio 3), sob a presidência do Magnífico Reitor da Universidade de São Paulo, Prof. Lineu Prestes, deu-se a instalação da nova Faculdade de Arquitetura, seguindo-se a posse do Prof. Christiano Stockler das Neves no cargo de Diretor. ${ }^{12}$ A data de instalação da Faculdade de Arquitetura fora sugerida pelo presidente do Confea, o Engenheiro-Arquiteto Adolfo Morales de los Rios Filho, também presente na solenidade, nos seguintes termos: "Aproveito a oportunidade para sugerir-lhe o dia 12 de agosto - data em que se comemora a fundação dos cursos artísticos oficiais no Brasil - para a realização da solenidade" (UNIVERSIDADE PRESBITERIANA MACKENZIE, 1946-1950). Recorda-se que foi por decreto datado de 12 de agosto de 1826 que D. Pedro I criou a Academia Imperial de Belas Artes, da qual a Escola Nacional de Belas Artes se fez sucessora e cuja denominação mudou, em 1945, para Faculdade Nacional de Arquitetura - a primeira do Brasil. Essa data de 1826 assinala, simbolicamente, o início do ensino de Arquitetura no país, tendo à frente o Arquiteto Grandjean de Montigny (1776-1850), integrante da conhecida "Missão Francesa", presente no Brasil desde 1816.

Dois meses depois, ainda no contexto das comemorações alusivas à investidura do Prof. Christiano Stockler das Neves no cargo de Diretor da Faculdade - por aclamação da Congregação, dispensando-se Lista Tríplice - foi-Ihe oferecido um banquete que teve lugar no dia 29 de outubro, nos salões do Trianon. Nessa ocasião mais íntima, em meio a longas reminiscências sobre as origens e o desenvolvimento do Curso de Arquitetura até culminar com a fundação da Faculdade, o diretor fez uma instigante revelação:

\footnotetext{
Queremos vos dar uma notícia muito agradável, estamos certos. É o honroso convite que nos fez o Magnífico Reitor da Universidade de São Paulo, o ilustre Prof. Lineu Prestes, para tomarmos parte na organização da Faculdade de Arquitetura dessa Universidade, conjuntamente com os ilustres Professores Anhaia Mello e Henrique Jorge Guedes, todos nossos bons amigos. Será mais uma escola de arquitetura que terá São Paulo, o que bem demonstra o reconhecimento dos nossos dirigentes em relação ao papel importante que representa a arte milenar na civilização dos povos. Esse gesto elegante e nobre do Magnífico Reitor para com um antigo professor do Mackenzie veio estreitar, ainda mais, as nossas cordiais relações com os estabelecimentos oficiais de ensino cujos chefes bem compreendem os serviços que vem prestando o Mackenzie a São Paulo e ao Brasil. (ANUÁRIO, 1949, p. 190).
}

Por ocasião da abertura do ano letivo seguinte, em 15 de março de 1948, estando novamente presente o reitor da Universidade de São Paulo, Christiano Stockler das Neves proferiu longa e substanciosa 'aula inaugural', quando apresentou reflexões sobre a formação do Arquiteto e as funções que lhe competem - seu tema de predileção. Na sua mensagem inaugural, em que alternou registros narrativos com reflexões conceituais, foram reforçadas algumas significativas demarcações ideológicas e históricas. Eis a primeira: 
Graças à ação dos Congressos Internacionais de Arquitetos, alguns países começaram a compreender a verdadeira missão do arquiteto, e a necessidade de se tornar autônomo o ensino da grande arte milenar, para se desfazer a confusão reinante entre profissões análogas mas diversas. O Brasil está incluído entre os pioneiros dessa cruzada, tendo o Governo Federal criado as Faculdades de Arquitetura. A primeira estabelecida é a da Universidade do Brasil, a segunda a do Mackenzie, a primeira a funcionar em São Paulo. Ainda este ano deverá ser instalada a Faculdade de Arquitetura da Universidade de São Paulo. Outras virão por ser grande o número de candidatos à matrícula nas escolas existentes. (ANUÁRIO, 1948, p. 215).

Em outro trecho da sua mensagem, Christiano Stockler das Neves não deixa de reiterar as convicções ideológicas que vinha adotando e pretendia manter à frente da Faculdade de Arquitetura Mackenzie, em relação à Arquitetura como expressão do belo e como manifestação do espírito, ainda que em prejuízo do utilitarismo e de uma suposta modernidade, de inspiração materialista:

Continuaremos, assim, a seguir nesta Faculdade a mesma orientação do anterior curso que fundamos, sempre contrária à materialização da arquitetura, não nos impressionando a tenaz propaganda feita aquém e além-mar pelos apologistas da pseudoarte. Não é isto intolerância, intransigência ou prepotência, mas, sim, uma defesa natural da espiritualidade da arquitetura contra seus inimigos materialistas e aventureiros que, como disse De Chirico, para fazerem a América, fizeram-na ir na onda das baboseiras modernistas. Na Faculdade de Arquitetura essa onda não produzirá qualquer efeito. (ANUÁRIO, 1948, p. 219).

Segue-se, ainda, uma autêntica e contundente 'declaração de fé' do criador do Curso de Arquitetura do Mackenzie, depois fundador e primeiro diretor da Faculdade de Arquitetura:

Como brasileiro, que ama de coração o seu país; como católico, de espírito formado na sadia doutrina da moral cristã; como homem que sente, pela sua vida de consciência e cultura, que não é uma simples máquina de viver, nem um puro animal sem alma, convoco todos aqueles que não se acharem contaminados pelo vírus do bolchevismo a ficarem vigilantes na defesa da pátria, repudiando, pela crítica ou pelo desprezo, essa pretensa arte moderna, primitiva e grosseira, além de indiscutivelmente venenosa e suspeita. (ANUÁRIO, 1948, p. 224).

Teriam essas configurações alguma afinidade ideológica com o Instituto [Presbiteriano] Mackenzie e sua recém-fundada Faculdade de Arquitetura? Segundo Christiano Stockler das Neves, a resposta seria naturalmente positiva, mas uma análise de conteúdo mais crítica sugere desvincular algumas categorias e questionar a pertinência das conexões entre Cristianismo, ideologia e formação em Arquitetura: 


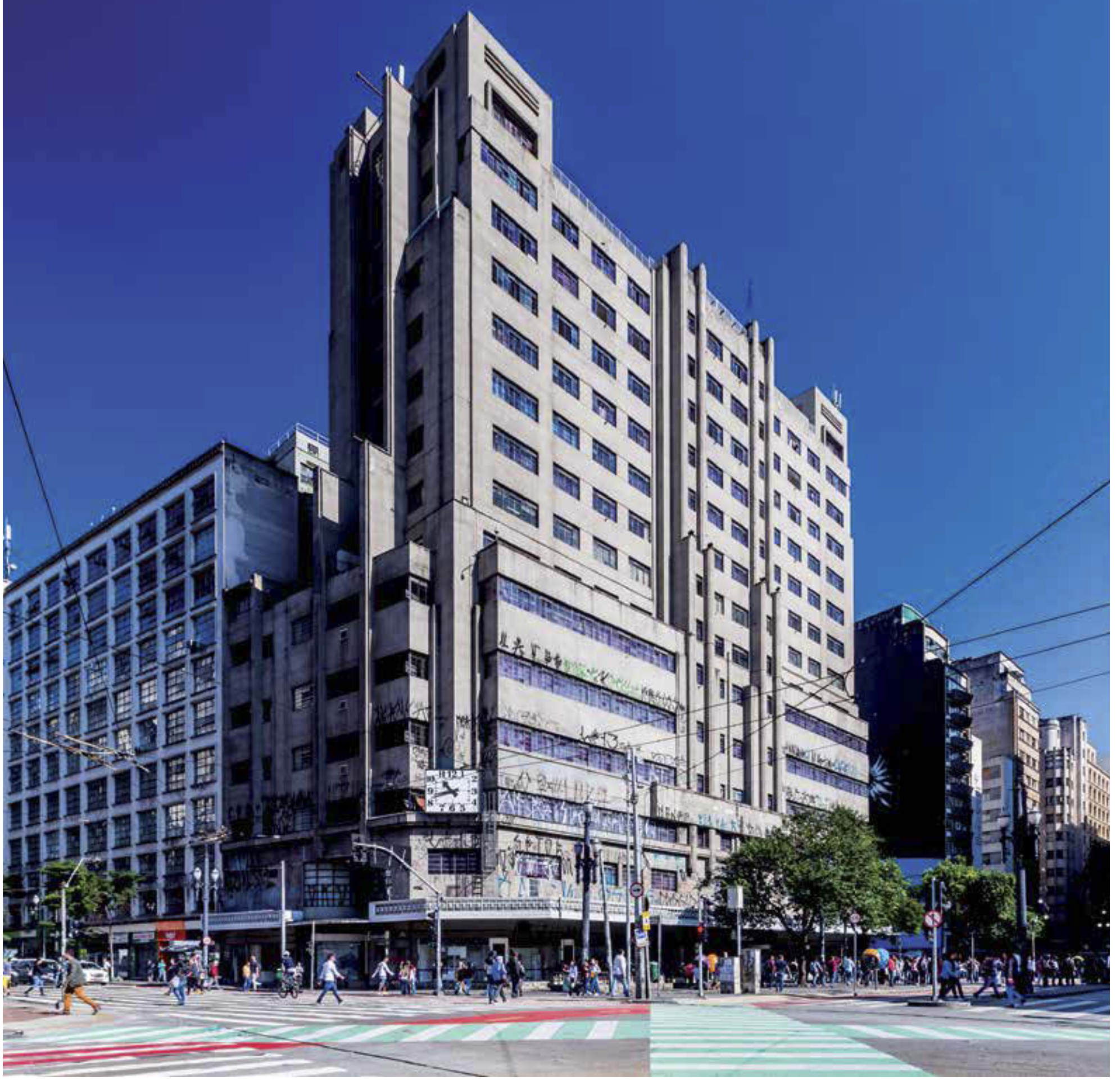


Mackenzie é uma instituição cristã e, em hipótese nenhuma, contribuirá para a destruição do sentimento do belo, da arte, enfim, não aprovando sua Faculdade de Arquitetura a prática ou a propaganda de uma pseudodoutrina estética, anticristã, insidiosa e maquiavélica, que pretende fazer desaparecer a maior das artes, a arte civilizadora, para transformá-la numa indústria, ao sabor dos insensíveis ao belo, que não trepidaram em falar na destruição dos quadros de Rafael e das galerias de arte. (ANUÁRIO, 1948, p. 224).

Os rumos seguidos pela Faculdade de Arquitetura Mackenzie pertencem a um novo contexto, não contemplado neste breve capítulo. Considerando, por outro lado, que "a história é a ciência dos homens, no tempo" (BLOCH, 2002, p. 55) impõe-se que busquemos nos arquivos antigos a nominata dos alunos do Curso de Arquitetura da Escola de Engenharia, antes de se transformar em Faculdade.

\section{Engenheiros-Arquitetos e Arquitetos formados (1919-1947)}

A missão de educar o ser humano para o exercício da cidadania e formar, simultaneamente, profissionais aptos para interagir com a complexidade do mundo contemporâneo sempre exigiu dos corpos diretivo e docente do antigo Curso de Arquitetura do Mackenzie uma forte intenção, esforço sincero, rumo inteligente e execução competente. O resultado mais evidente do sucesso dessa fórmula pode ser aquilatado pelo montante do 'capital de egressos', isto é, pela qualificada lista de profissionais formados entre 1919 e 1947 - marcos extremos correspondentes à formatura da primeira turma e da última turma, respectivamente, considerando que a partir do segundo semestre de 1947 já se configurou o formato da Faculdade de Arquitetura do Instituto Mackenzie, não mais Mackenzie College, não mais um curso apenso à Escola de Engenharia. Do ponto de vista de Christiano Stockler das Neves, fundador do Curso de Arquitetura do Mackenzie College e primeiro Diretor da Faculdade de Arquitetura do Instituto Mackenzie, esse 'capital de egressos' era amplo, denso e relevante:

Grande é o número de arquitetos formados no Mackenzie. Muitos, hoje, são profissionais de renome, portadores de altas recompensas, obtidas em exposições internacionais de arquitetura, que fizeram o Mackenzie conhecido além de nossas fronteiras. A atividade dos arquitetos mackenzistas faz-se sentir em todos os recantos do País, principalmente nessa Capital, onde são inúmeras as situações por eles projetadas e executadas. Do Mackenzie tem saído o maior número de arquitetos do Estado. Muitos desempenharam funções públicas de destaque. (ANUÁRIO, 1949, p. 172)

Diante desse balanço tão positivo, feito na data de instalação da Faculdade, surge a inevitável pergunta: Quais foram esses ilustres engenheiros(as)-arquiteto(as) e arquitetos(as) que frequentaram os espaços acadêmicos do Mackenzie? Passamos a apresentar o rol de todos os formados nesse período, que totaliza 90 profissionais (ANUÁRIO, 1960, p. 52-54; ANUÁRIO, 1949, p. 145)
Na página anterior:

Edifício João Brícola (antigo Mappin), na região central de São Paulo, 1936. Autoria do Professor e Arquiteto Elisiário da Cunha Bahiana (ENBA, 1920), também autor do Viaduto do Chá, conjunto realizado no estilo Art-Déco. 
Quadro 2 - Engenheiros-Arquitetos formados no período de 1919-1947 (continua).

\begin{tabular}{|c|c|c|}
\hline Ano & Nome & Título Profissional \\
\hline 1919 & Waldemar Kneese Ferreira & Engenheiro-Arquiteto \\
\hline \multirow{3}{*}{1920} & Antonio Gomes Barreiros & Engenheiro-Arquiteto \\
\hline & Caetano Carnicelli & Engenheiro-Arquiteto \\
\hline & Romeu do Amaral & Engenheiro-Arquiteto \\
\hline \multirow{3}{*}{1922} & Antonio Gallo Ferrigno & Engenheiro-Arquiteto \\
\hline & José do Amaral Neddermeyer & Engenheiro-Arquiteto \\
\hline & Renato Ribeiro de Aguiar & Engenheiro-Arquiteto \\
\hline \multirow{2}{*}{1923} & Armênio de Lima Goes & Engenheiro-Arquiteto \\
\hline & Salomão Rosa & Engenheiro-Arquiteto \\
\hline \multirow{2}{*}{1924} & Francisco de Paula Silveira & Engenheiro-Arquiteto \\
\hline & João dos Santos Filho & Engenheiro-Arquiteto \\
\hline \multirow{5}{*}{1925} & Antonio Cassese & Engenheiro-Arquiteto \\
\hline & Francisco José Esteves Kosuta & Engenheiro-Arquiteto \\
\hline & Guilherme Corazza & Engenheiro-Arquiteto \\
\hline & Henrique Franzoni & Engenheiro-Arquiteto \\
\hline & Ítalo Martinelli & Engenheiro-Arquiteto \\
\hline \multirow{3}{*}{1926} & Alexandre Cesar Cococci & Engenheiro-Arquiteto \\
\hline & José Bastos Silva & Engenheiro-Arquiteto \\
\hline & Miguel Próta & Engenheiro-Arquiteto \\
\hline \multirow{8}{*}{1927} & Álvaro David do Valle & Engenheiro-Arquiteto \\
\hline & Francisco Souza Rocha Jr. & Engenheiro-Arquiteto \\
\hline & Joaquim Marques Ladeira & Engenheiro-Arquiteto \\
\hline & José Dias da Gama & Engenheiro-Arquiteto \\
\hline & Oswaldo Barreto Robinson & Engenheiro-Arquiteto \\
\hline & Plínio Botelho do Amaral & Engenheiro-Arquiteto \\
\hline & Renato De Guglielmo & Engenheiro-Arquiteto \\
\hline & Ruy Fernandes Seixas & Engenheiro-Arquiteto \\
\hline \multirow{4}{*}{1928} & Alcides Xande & Engenheiro-Arquiteto \\
\hline & Luiz Del Nero & Engenheiro-Arquiteto \\
\hline & Raul Freire de Mattos Barretto & Engenheiro-Arquiteto \\
\hline & Vicente Del Monaco & Engenheiro-Arquiteto \\
\hline \multirow{3}{*}{1929} & Fernando Alberto Gama Rodrigues & Engenheiro-Arquiteto \\
\hline & Max Hans Förtner & Engenheiro-Arquiteto \\
\hline & Zilda de Almeida Sampaio & Engenheira-Arquiteta \\
\hline \multirow{7}{*}{1930} & Alfredo Cecílio Lopes & Engenheiro-Arquiteto \\
\hline & Antonio Tadeu Giuzio & Engenheiro-Arquiteto \\
\hline & Armando Ciampolini & Engenheiro-Arquiteto \\
\hline & Américo Capua & Engenheiro-Arquiteto \\
\hline & Décio da Silva Pacheco & Engenheiro-Arquiteto \\
\hline & Jaime C. Fonseca Rodrigues & Engenheiro-Arquiteto \\
\hline & José Perroni Jr. & Engenheiro-Arquiteto \\
\hline
\end{tabular}


Quadro 2 - Engenheiros-Arquitetos formados no período de 1919-1947 (continuação).

\begin{tabular}{|c|c|c|}
\hline Ano & Nome & Título Profissional \\
\hline 1930 & Oswaldo Arthur Bratke & Engenheiro-Arquiteto \\
\hline \multirow{5}{*}{1931} & Alberto Schirato & Engenheiro-Arquiteto \\
\hline & Carlos Amélio Botti & Engenheiro-Arquiteto \\
\hline & Eduardo A. Kneese de Mello & Engenheiro-Arquiteto \\
\hline & Olívia Barros do Amaral & Engenheira-Arquiteta \\
\hline & Vicente Nigro Jr. & Engenheiro-Arquiteto \\
\hline \multirow{7}{*}{1932} & Antonio de Lucca & Engenheiro-Arquiteto \\
\hline & Augusto Pedalini & Engenheiro-Arquiteto \\
\hline & Ferdinando Filippi & Engenheiro-Arquiteto \\
\hline & Henrique Ephim Mindlin & Engenheiro-Arquiteto \\
\hline & Mário Zerbini & Engenheiro-Arquiteto \\
\hline & Otávio Lotufo & Engenheiro-Arquiteto \\
\hline & Vicente Miceli & Engenheiro-Arquiteto \\
\hline 1933 & Takeshi Suzuki & Engenheiro-Arquiteto \\
\hline \multirow{2}{*}{1934} & Francisco José Dale Caiuby & Engenheiro-Arquiteto \\
\hline & Walter Saraiva Kneese & Engenheiro-Arquiteto \\
\hline \multirow{2}{*}{1937} & Manoel Carlos G. de Soutello & Engenheiro-Arquiteto \\
\hline & Maurício dos Santos Cruz & Engenheiro-Arquiteto \\
\hline \multirow{5}{*}{1939} & Galiano Ciampaglia & Arquiteto \\
\hline & Igor Sresnewsky & Arquiteto \\
\hline & Manoel Amadeu G. de Soutello & Arquiteto \\
\hline & Miguel Forte & Arquiteto \\
\hline & Sophie Elma M. Capps & Arquiteta \\
\hline \multirow{3}{*}{1940} & Irene Sapojkin & Arquiteta \\
\hline & Jacob Maurício Ruchti & Arquiteto \\
\hline & Nelson Pugliese & Arquiteto \\
\hline \multirow{5}{*}{1941} & Domingos Vitorio Jannini & Arquiteto \\
\hline & Francisco A. S. Fanuele & Arquiteto \\
\hline & João Bernardes Ribeiro & Arquiteto \\
\hline & Lauro da Costa Lima & Arquiteto \\
\hline & Maria Armelinda Hoenen & Arquiteta \\
\hline 1942 & Hugo Edmundo Kuhi & Arquiteto \\
\hline \multirow{2}{*}{1943} & Fernando Behn de Aguiar & Arquiteto \\
\hline & Mauro Alves dos Santos & Arquiteto \\
\hline \multirow{4}{*}{1944} & Egberto F. de A. Camargo & Arquiteto \\
\hline & Fernando Martins Gomes & Arquiteto \\
\hline & Gustavo Caron & Arquiteto \\
\hline & João Francisco Portilho de Andrade & Arquiteto \\
\hline \multirow{3}{*}{1945} & Arnaldo Guimarães Senna & Arquiteto \\
\hline & Jandovy Lui & Arquiteto \\
\hline & Osvaldo de Aguiar Pupo & Arquiteto \\
\hline
\end{tabular}




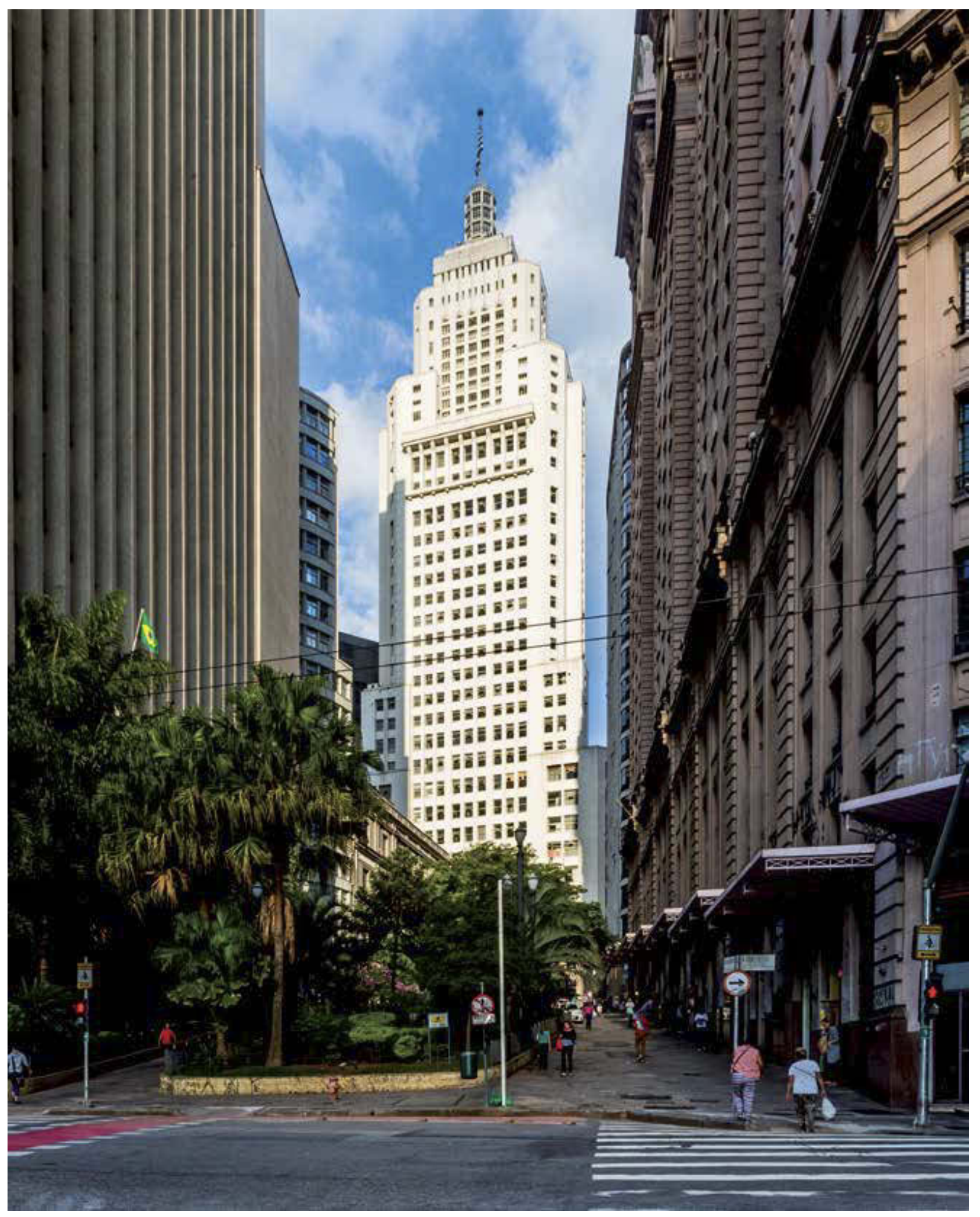


Quadro 2 - Engenheiros-Arquitetos formados no período de 1919-1947 (continuação).

\begin{tabular}{lll} 
Ano & Nome & Título Profissional \\
\hline 1945 & Wiliam Henz Gorham & Arquiteto \\
\hline \multirow{3}{*}{1946} & Jorge José Proushan & Arquiteto \\
\cline { 2 - 3 } & Nelson Carmo F. Pedalini & Arquiteto \\
\cline { 2 - 3 } & Plinio Croce & Arquiteto \\
\cline { 2 - 3 } & Roberto Fonetti & Arquiteto \\
\cline { 2 - 3 } & Roger Henri Weiler & Arquiteto \\
\hline \multirow{2}{*}{1947} & Carlos Henrique Bahiana & Arquiteto \\
\cline { 2 - 3 } & Nilo Ramos Villaboim & Arquiteto
\end{tabular}

Fontes: ANUÁRIO (1961, p. 52-54) e ANUÁRIO (1949, p. 145)

Entre essas nove dezenas de engenheiros-arquitetos e arquitetos mackenzistas, é evidente que alguns nomes se destacam pela notoriedade alcançada no meio profissional ou acadêmico. Mencioná-los seria arriscado, pois teríamos que ter critérios prévios para avaliar o brilho acadêmico de cada um, ou captar o impacto das respectivas trajetórias profissionais. É trabalho para outro contexto.

Para encerrar o capítulo, não poderíamos deixar de ressaltar ainda a densidade de circunstâncias e de elementos de contorno de que se cercaram as três décadas iniciais do Curso de Arquitetura. Do ponto de vista institucional, o Curso começa no âmbito do Mackenzie College, passa à esfera do Instituto Mackenzie (a partir de 1940) e prepara a plataforma para a criação da Universidade, que passaria a funcionar cinco anos depois da transformação do Curso em Faculdade.

No âmbito nacional, o Curso de Arquitetura nasce durante a República Velha, sobrevive à Gripe Espanhola de 1918, supera os efeitos dos Movimentos Revolucionários de 1924, 1930 e 1932; ingressa na "era Vargas", coexiste com o Estado Novo (1937-1945), convive com quatro versões da Constituição Brasileira (1891, 1934, 1937 e 1946) e respira os ares da redemocratização iniciada em 1946. Finalmente, em termos mundiais, observa a Revolução Comunista de 1917 e a criação da União Soviética; presencia o final da Primeira Grande Guerra e a assinatura do Tratado de Versalhes; transpõe com êxito a Grande Depressão de 1929; toma conhecimento da instalação dos regimes fascista e nazista; testemunha o começo, o desenrolar e o final da Segunda Guerra Mundial; impressiona-se com as bombas atômicas lançadas sobre Hiroshima e Nagasaki, para, então, ainda ver nascer nas latitudes do Norte a célebre "Guerra Fria". Tudo isso, sem se falar da evolução estonteante da espiral científico-tecnológica, que inaugura a era da eletrônica, que vai da régua de cálculo à calculadora eletromecânica, do automóvel Ford Modelo T ao luxuoso Cadillac, da pena de aço à caneta Parker, do cinema mudo à televisão, do avião "teco-teco" às bombas voadoras. Enfim, começa-se com o título de Engenheiro-Architecto e termina-se com o glorioso título de Arquiteto. Tudo isso, repita-se, em apenas trinta anos!
Na página anterior:

Edifício Altino Arantes (Edifício Banespa), Av. São João, São Paulo, 1939. Autoria do Engenheiro-Arquiteto Plínio Botelho do Amaral (Mackenzie, 1927). 


\section{Referências}

ABRUNHOSA, E. C. Modernos conservadores ou clássicos progressistas: a construção do ideário moderno na Faculdade de Arquitetura Mackenzie (1947-1968). 2016. Dissertação (Mestrado em Arquitetura e Urbanismo)-Universidade Presbiteriana Mackenzie, São Paulo, 2016.

ANUÁRIO, da Escola de Engenharia Mackenzie, 1934. São Paulo: Instituto Mackenzie, 1935, v. 1. ANUÁRIO da Escola de Engenharia Mackenzie, 1936. São Paulo: Instituto Mackenzie, 1937, v. 3. ANUÁRIO da Escola de Engenharia Mackenzie, 1938. São Paulo: Instituto Mackenzie, 1939, v. 5. ANUÁRIO da Escola de Engenharia Mackenzie, 1939. São Paulo: Instituto Mackenzie, 1940, v. 6. ANUÁRIO da Escola de Engenharia Mackenzie, 1941. São Paulo: Instituto Mackenzie, 1942, v. 8. ANUÁRIO da Escola de Engenharia Mackenzie, 1942. São Paulo: Instituto Mackenzie, 1943, v. 9.

ANUÁRIO da Escola de Engenharia Mackenzie, 1943-1944 (Compreende os anos de 1943 e 1944). São Paulo: Instituto Mackenzie, 1944, v. 10.

ANUÁRIO da Escola de Engenharia Mackenzie, 1945-1948 (Compreende os anos de 1945 a 1948). São Paulo: Instituto Mackenzie, 1949, v. 11-14.

ANUÁRIO da Escola de Engenharia Mackenzie, 1949-1951 (Compreende os anos de 1949 a 1951). São Paulo: Instituto Mackenzie, 1952, v. 15.

ANUÁRIO da Escola de Engenharia Mackenzie, 1952. São Paulo: Universidade Mackenzie, 1953, v. 16.

ANUÁRIO da Escola de Engenharia Mackenzie, 1955. São Paulo: Universidade Mackenzie, 1956, v. 19.

ANUÁRIO da Escola de Engenharia Mackenzie, 1960. São Paulo: Universidade Mackenzie, 1961, v. 24.

ATIQUE, F. Arquitetando a "Boa Vizinhança": a sociedade urbana do Brasil e a recepção do mundo norte-americano, 1876-1945. 2007. Tese (Doutorado em História e Fundamentos da Arquitetura e do Urbanismo)-Universidade de São Paulo, São Paulo, 2007.

Os elos entre a University of Pennsylvania e a arquitetura do Brasil, através da trajetória profissional de George Henry Krug. 19\&20 Magazine, IV, v. 1, 2009.

Os Diplomados em Arquitetura na "University of Pennsylvania" e suas Trajetórias no Brasil. In: ENANPARQ, 1., simpósio temático: leituras, diálogos e conflitos: as relações no espaço construído e imaginado entre Brasil, América e Europa, 2010, São Paulo. Anais... São Paulo: Enanparq, 2010.

BLOCH, M. Apologia da história - ou o ofício de historiador. Tradução André Telles. Rio de Janeiro: Jorge Zahar Editor, 2002.

BREIA, M. T. de S. e. O ensino de arquitetura e Christiano Stockler das Neves. 1995. Dissertação (Mestrado em Arquitetura e Urbanismo)-Universidade Presbiteriana Mackenzie, São Paulo, 1995. 
CIAMPAGLIA, F. Galiano Ciampaglia. Razões de uma arquitetura. 2012. Dissertação (Mestrado em História e Fundamentos da Arquitetura e do Urbanismo)-Universidade de São Paulo, São Paulo, 2012.

DE LORENZO, H. C.; COSTA, W. P. da (Org.). A década de 1920 e as origens do Brasil moderno. São Paulo: Editora da Unesp, 1997.

ESCOLA AMERICANA; MACKENZIE COLLEGE. [Prospecto]. São Paulo, 1914-1915.

ESCOLA AMERICANA; MACKENZIE COLLEGE. [Prospecto]. São Paulo, 1919-1920.

FICHER, S. Ensino e Profissão: o curso de Engenheiro-Arquiteto da Escola Politécnica de São Paulo. 1989. Tese (Doutorado em História)-Universidade de São Paulo, São Paulo, 1989. Os arquitetos da Poli: Ensino e Profissão em São Paulo. São Paulo: Fapesp: Edusp, 2005.

HOMEM, M. C. N. Higienópolis: Grandeza de um Bairro Paulistano. 2. ed. rev. e ampl. São Paulo: Edusp, 2011.

MACKENZIE COLLEGE. Annual report to the Board of Trustees. São Paulo, [1922].

MENDES, M. Mackenzie no espelho. São Paulo: Editora Mackenzie, 2000. Tempos de transição. 2. ed. São Paulo: Editora Mackenzie, 2016.

PEREIRA, G. Christiano Stockler das Neves e a formação do curso de Arquitetura no Mackenzie College. 2005. Dissertação (Mestrado em Arquitetura)-Universidade Presbiteriana Mackenzie, São Paulo, 2005.

REVISTA DE ENGENHARIA MACKENZIE. São Paulo: Instituto Mackenzie, v. 6, n. 48, set. 1928. REVISTA DE ENGENHARIA MACKENZIE. São Paulo: Instituto Mackenzie, v. 7, n. 52-53, jun. 1930. REVISTA DE ENGENHARIA MACKENZIE. São Paulo: Instituto Mackenzie, v. 14, n. 81, fev. 1943. REVISTA DE ENGENHARIA MACKENZIE. São Paulo: Instituto Mackenzie, v. 15, n. 85, mar. 1944. REVISTA DE ENGENHARIA MACKENZIE. São Paulo: Instituto Mackenzie, v. 37, n. 111-112, mar.jun. 1952.

SOMEKH, N. A cidade vertical e o urbanismo modernizador. 2. ed. São Paulo: Editora Mackenzie: Romano Guerra, 2014.

UNIVERSIDADE PRESBITERIANA MACKENZIE. Escola de Engenharia. Correspondência. São Paulo, [período: 1946-1950]. Volume encadernado.

UNIVERSIDADE PRESBITERIANA MACKENZIE. Escola de Engenharia. Programas das matérias dos cursos de Engenharia. São Paulo, [período: 1927]. Volume encadernado.

UNIVERSIDADE PRESBITERIANA MACKENZIE. Escola de Engenharia. Livro de Atas N. 1, da Congregação da Escola de Engenharia. São Paulo, [período: 1923-1940]. Volume encadernado. 
s/d. Alunos em sala de aula realizando

atividades de desenho do Curso

de Arquitetura.

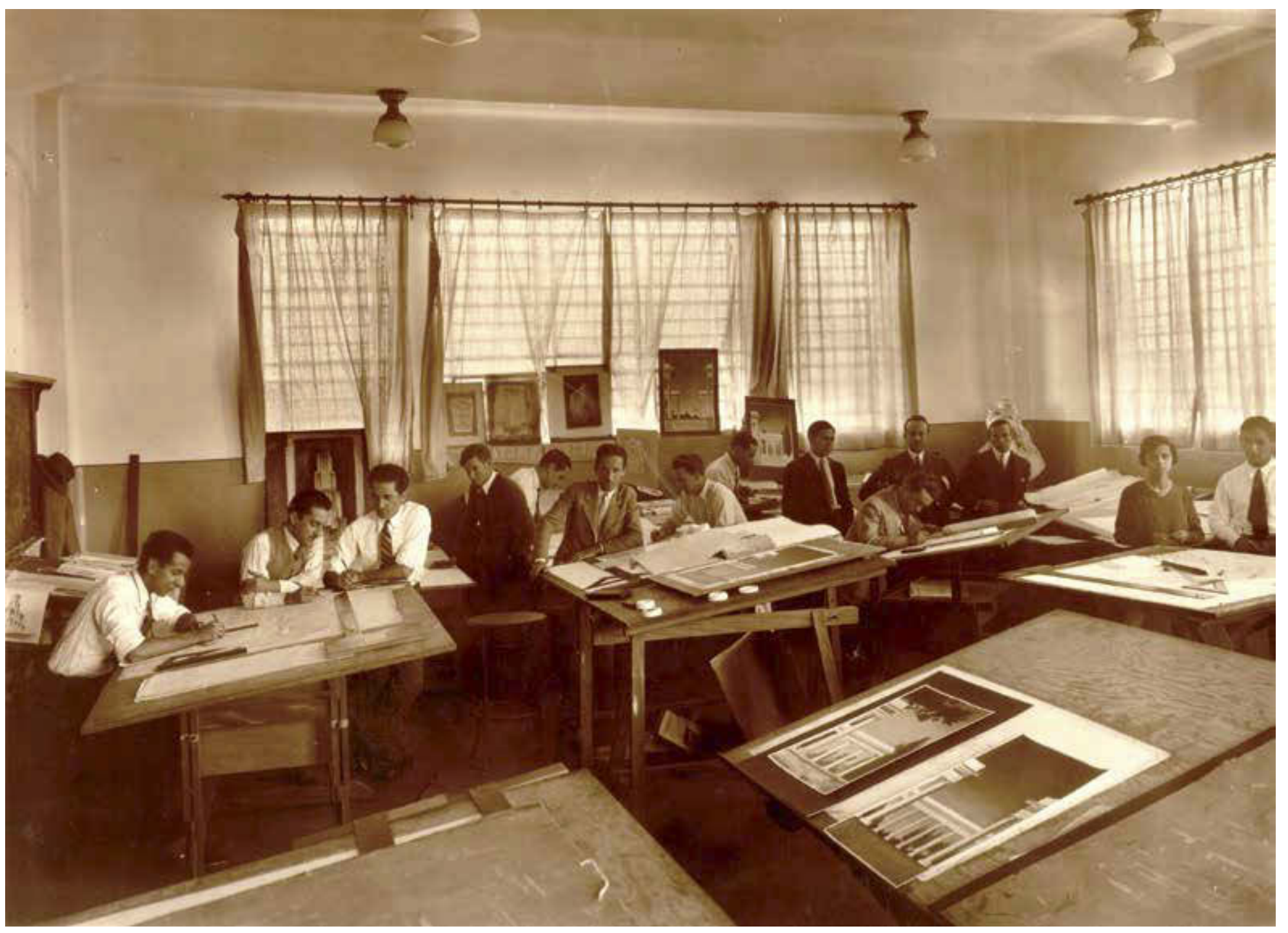

